\title{
Law and Macroeconomics: The Law and Economics of Recessions
}

\author{
Yair Listokin ${ }^{\dagger}$
}

In this Article, I offer a macroeconomic perspective on law that reshapes the microeconomic perspective that currently dominates law and economics. I argue that, first, the economy works one way in ordinary economic conditions, in which supply capacity determines output, and a different way when interest rates are zero. At the "zero lower bound" on short-term interest rates, spending demand determines output. Second, because the economy functions differently at the zero lower bound, a law causes one set of effects at the zero lower bound and a different set of effects at other times. And third, because the same law has different effects at different times, law should be different at the zero lower bound than in other times. Specifically, law should do more to promote spending when the macro-economy is characterized by zero interest rates than in ordinary economic conditions. Because the stakes of recessions in which interest rates hit the zero lower bound are so high-for instance, tens of trillions of dollars in lost output, countless lives impaired, and a much higher likelihood of political upheavals like Donald Trump's ascendancy to the U.S. Presidency I argue that the (significant) costs associated with introducing macroeconomics into law are worth bearing.

Introduction

A. The Economy Works One Way in Ordinary Economic

Conditions and a Different Way at the Zero Lower Bound

B. Laws Cause One Set of Effects at the Zero Lower Bound and Another Set of Effects in Ordinary Economic Conditions

C. Laws Should Be Different at the Zero Lower Bound than in Other Times

I. Law and Macroeconomics: A Literature Review

II. The Economic and Social Costs of the Great Recession

A. Economic Costs

B. Political Costs: Populism and the Great Recession 807

$\dagger \quad$ Shibley Family Fund Professor of Law, Yale Law School. I thank Inho Andrew Mun for truly superb research assistance. I also thank Bruce Ackerman, Ian Ayres, Heather Gerken, David Grewal, Jonathan Klick, Zach Liscow, Nicholas Parrillo, Roberta Romano, and John Witt for many helpful conversations and comments. I thank seminar participants at Yale, Stanford, Boston College, Duke, Hebrew University, Tel Aviv University, Haifa University, and Bar-Ilan University Law Schools for their lively feedback and discussion. All errors are my own. 
III. The Economy Works One Way in Ordinary Economic Conditions and

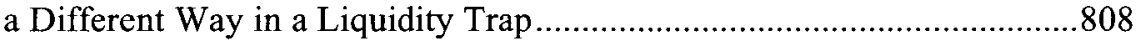

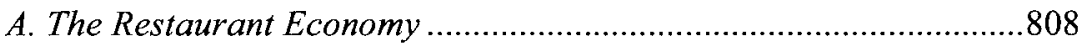

B. Interest Rates and the Restaurant Economy ..................................809

C. Macroeconomic Conditions at the Zero Lower Bound on Interest Rates

D. Why the Economy Functions Differently in Zero Lower Bound Recessions Than at Other Times...

1. The Interest Rate Does Not Equilibrate Capacity and

Aggregate Demand

2. Inefficacy of Monetary Policy ...............................................815

E. IS-LM and the Zero Lower Bound ...............................................817

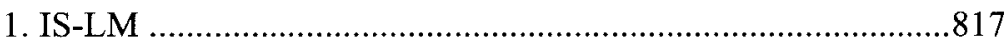

2. IS-LM and the Zero Lower Bound on Interest Rates ...............820

3. Differential Impacts of Monetary Policy at the Zero Lower Bound and In Ordinary Times

4. Differential Impacts of Fiscal Policy at the Zero Lower

Bound and in Other Times

F. Empirical Evidence that Economic Policies Have Different

Effects at Different Times

IV. Laws Cause One Set of Effects In Liquidity Traps and Another Set of

Effects in Ordinary Economic Conditions.

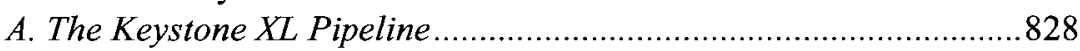

B. Cost Benefit Analysis of the Keystone XI Pipeline .........................831

C. Conditional Approvals and Aggregate Demand............................835

D. Remedies in Contract .................................................................836

V. Laws Should Be Different at the Zero Lower Bound ................................838

VI. Institutional Barriers to Law and Macroeconomics ................................8.839

A. Critiquing Law and Macroeconomics in Practice .........................839

1. The Likelihood of Effective Law and Macroeconomic

Policymaking Is Low

2. The Costs of Considering Macroeconomics in Legal

Decisions Are High

3. There Are Better Venues than Law for Making

Macroeconomic Policy

a. Monetary Policy .............................................................842

b. Fiscal Policy ...................................................................843

B. Why Law and Macroeconomics Applies in Practice as Well as

Theory During Liquidity Traps

1. The Stakes Are So High and the Alternatives Are Weak .........844

2. Are the Costs of Using Law for Macroeconomic Ends

Really So High?.

3. Macroeconomic Considerations Will Be One Factor Among Many for Legal Policy Decisions 
C. Implementing Law and Macroeconomics ...................................852

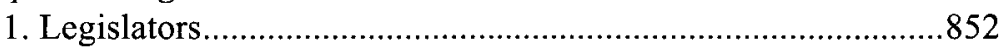

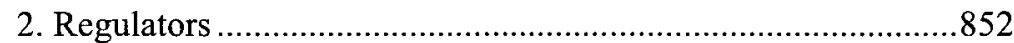

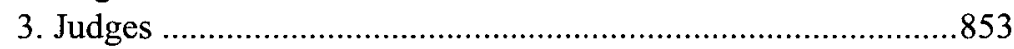

4. Enforcement Officers........................................................... 853

5. Law and Macroeconomics Already in Place ..........................853

Conclusion

\section{Introduction}

In this Article, I make three claims. Together, they present a macroeconomic perspective on law that differs from the microeconomic perspective that currently dominates law and economics.

(1) The macro-economy works one way in ordinary economic conditions (when interest rates comfortably exceed zero) and a different way when short-term interest rates hit zero (a condition known as a "liquidity trap" or the "zero lower bound" on interest rates). ${ }^{1}$

(2) Because the economy functions differently at the zero lower bound than in ordinary times, a law causes one set of effects at the zero lower bound and a different set of effects at other times.

(3) Because the same law has different effects at different times, law should be different at the zero lower bound than at other times. Specifically, law should do more to promote spending at the zero lower bound.

\section{A. The Economy Works One Way in Ordinary Economic Conditions and a Different Way at the Zero Lower Bound}

During ordinary economic times - which I will define to mean periods in which the short-term interest rate exceeds zero, the economy's capacity to supply ${ }^{2}$ goods and services determines long-run economic output. ${ }^{3}$ In turn,

1. I will use the terms "liquidity trap" and "zero lower bound" interchangeably in this Article. A liquidity trap describes an economic condition where the interest rates in the economy are so close to zero such that the central bank cannot lower the interest rates in the economy any further to pursue monetary policies (i.e., monetary policies become impotent). See MANKIW, infra note 4, at 33. In a liquidity trap, interest rate movements are constrained by this "zero lower bound" on interest rates. For more discussion of the causes of the zero lower bound, see infra Sections III.C-D.

2. "Aggregate supply" is defined as "[t]he total amount of real goods and services that the enterprises in an economy are willing to provide at any given ratio of prices to wages." JOHN BLACK ET AL., A DICTIONARY OF ECONOMICS 8 (2012).

3. In macroeconomics, the concepts of economic output, employment, and national income are largely interchangeable. In the aggregate demand and aggregate supply curve mapped onto a two-dimensional space, the $y$-axis captures price and the $x$-axis can be any one of economic output, employment, and national income. 
capacity is determined by the size of the labor force, the stock of capital (including human capital), and an economy's technological prowess. ${ }^{4}$ The only way to increase output over the long run is by increasing one of these supply factors.

Interest rates adjust to bring spending into balance with capacity. When spending in the economy - known as "aggregate demand"5-temporarily does not equal production capacity (causing a temporary boom or recession), changes in interest rates help end the disparity. With excess spending demand (a short-run boom), interest rates rise, making spending less attractive relative to saving and reducing spending so that it equals capacity. If spending is too low (causing a temporary recession), then interest rates decrease, prompting more spending on consumption and investment. Central banks use their control over the money supply, an important determinant of interest rates, to hasten this macroeconomic adjustment process.

Because interest rates adjust to offset the effects of changes of aggregate demand, polices that stimulate aggregate demand, such as increasing government expenditures or lowering taxes, do not raise output over the long run. Instead, stimulus policies may temporarily cause output to increase, but in the long-run they just raise interest rates and reshuffle output from one place to another.

Not so when short-term interest rates hit the zero lower bound on interest rates. Because cash (and equivalents like checking accounts) offer an interest rate of zero, most assets cannot offer negative interest rates. If the yield on an asset falls well below zero, then people will shift their asset holdings to cash and checking accounts. Interest rates on assets are therefore bounded by zerothey cannot go (significantly) lower.

At the zero lower bound, the economy loses its macroeconomic equilibrating mechanism-the interest rate. If aggregate demand falls short of the economy's supply capacity at the zero lower bound, then the interest rate does not fall to bring aggregate demand back into balance with supply capacity. The interest rate has gone as low as it can go. With inadequate aggregate demand and no interest rate adjustment, labor and/or capital can sit idle for prolonged periods.

The zero lower bound also renders central banks impotent. Central banks' primary policy lever, expanding the money supply to lower interest rates and stimulate spending, ceases to be effective when interest rates are zero and cannot decrease further.

4. See TODD A. KNOPP, RECESSIONS AND DEPRESSIONS: UNDERSTANDING BUSINESS CYCles 35 (2d. ed. 2009); N. GREGORY MANKIW, MACROECONOMICS 49-5I (8th ed. 2012)

5. Aggregate demand is defined as "[t]he total of intended or ex ante attempts to spend on final goods and services produced in a country." BLACK ET AL., supra note 2, at 8 . It is the sum of consumption, investment, government spending on goods and services, and export demand minus imports. See id. 
The costs of inadequate aggregate demand and lost output at the zero lower bound can be staggering. In the Great Recession of 2008-2016, lost output in the U.S. measured approximately $\$ 6$ to $\$ 14$ trillion dollars. ${ }^{6}$ And the costs were unevenly distributed-the long-term unemployed suffered enormously while those who retained their jobs were relatively unaffected.

Incredibly, the economic costs pale in comparison to the threat posed by liquidity traps to political order. The last two instances of zero interest rate liquidity traps in the U.S. and Western Europe-the Great Depression of the 1930 s and the Great Recession of 2008-2016-witnessed confounding changes in political orders. The Great Depression fostered the rise of fascism and World War II. The Great Recession enabled the rise of populist nationalists like Donald Trump in the U.S. and like-minded movements in many European countries. While the Trump presidency has only just started, it represents a dramatic break in the continuity of the American political system. The longterm social and economic costs of such political upheavals are incalculable.

Given these costs, policies that mitigate zero lower bound recessions become urgent during liquidity traps. In a liquidity trap, aggregate demand stimulus policies, such as increased government spending or tax cuts, can raise output over the long term. Increases in spending raise output by utilizing some of the excess supply capacity in the economy. Keynesian aggregate demand stimulus policies that may be unwise during ordinary economic times become efficient and urgently necessary at the zero lower bound.

I should emphasize that the dependence of economics on business cycle and interest rate conditions is not a new macroeconomic claim. In 1937, John Hicks, one of the most important economists of the 20th century, faced a quandary: how could he reconcile the "classical" supply and demand economics that he was doing so much to advance with the Keynesian critique of this classical theory that provided a better account of the Great Depression of the 1930s?

Hicks's resolution of this quandary, presented in Mr. Keynes and the "Classics"; A Suggested Interpretation, ${ }^{7}$ provided the starting point for much of modern macroeconomics. ${ }^{8}$ Hicks suggested that classical supply and demand theory described a healthy economy with interest rates above zero, while

6. See David Luttrell, Tyler Atkison \& Harvey Rosenblum, Assessing the Costs and Consequences of the 2007-09 Financial Crisis and Its Aftermath, 8 DALLAS FED. ECON. LETTER 1-4 (Sept. 2013), http://www.dallasfed.org/research/eclett/2013/el1307.cfm.

7. See John Hicks, Mr. Keynes and the "Classics"; A Suggested Interpretation, 5 ECONOMETRICA 147 (1937).

8. In this paper, Hicks proposed the IS-LM curve, which became the foundation of modern macroeconomics. See, e.g., WARREN YOUNG \& BEN-ZION ZILBERFARB, IS-LM AND MODERN MACROECONOMICS 1 (2012) ("Dombusch and Fischer termed [Hicksian IS-LM] as "core of modern macroeconomics." "); Paul Krugman, How Complicated Does the Model Have To Be?, 16 OXFORD REV. ECON. POL'Y 33, 34 (2000); Paul Krugman, Tl; dr and Modern Macroeconomics, N.Y. TIMES (June 20, 2016), http://krugman.blogs.nytimes.com/2016/06/20/tldr-and-modern-macroeconomics-wonkish. 
Keynesian economics described liquidity traps. ${ }^{9}$ In other words, the economy works one way in ordinary times, and a different way at the zero lower bound. Hicks's theory has received considerable support from modern economic work on the Great Recession.

The liquidity trap is no mere theoretical curiosity. It described macroeconomic conditions in the Great Depression and the Great Recession. Moreover, the decline in long-term interest rates worldwide means that zero short-term interest rates will be increasingly common going forward. One recent paper estimated that "short-term interest rates could be at or very close to zero (that is, the Zero Lower Bound could be binding) as much as $30-40$ percent of the time." 10

In traditional law and economics, by contrast, the economy always works the same way. New spending is irrelevant; it just reshuffles output, rather than utilizing unused capacity. In effect, law and economics simply assumes that the economy is working normally and that output is never constrained by demand-an assumption that ignores the century-old field of macroeconomics that was initiated by the works of Keynes and Hicks.

\section{B. Laws Cause One Set of Effects at the Zero Lower Bound and Another Set of Effects in Ordinary Economic Conditions}

If economies work differently when interest rates are zero than when interest rates exceed zero, then laws have business-cycle dependent economic effects. Legal rulings that promote spending have little effect on economic output during ordinary times; they only move output in the direction mandated by legal rulings and away from areas the law does not favor. In a zero lower bound recession, by contrast, legal rulings that promote spending can increase output by drawing idle capacity back into production.

To illustrate the business cycle varying impacts of law, consider the State Department's consideration of the 2008 proposal by TransCanada, Inc. to build the 1,179-miles long Keystone XL oil pipeline from Hardisty, Alberta in Canada to Steele City, Nebraska ${ }^{11}$ as the last stage in a four-phase pipeline project.

With interest rates above zero-the world assumed by traditional law and economics and the world in which President Trump authored a memorandum in

9. See Hicks, supra note 7, at 154-55.

10. Ben Bernanke, How Big a Problem is the Zero Lower Bound on Interest Rates?, BROOKINGS (Apr. 12, 2017), http://www.brookings.edu/blog/ben-bernanke/2017/04/12/how-big-aproblem-is-the-zero-lower-bound-on-interest-rates (citing Michael Kiley \& John Roberts, Monetary Policy in a Low Interest Rate World (Brookings Papers on Economic Activity, 2017), http://www.brookings.edu/wp-content/uploads/2017/03/5_kileyroberts.pdf).

11. See About the Keystone XL Pipeline, TRANSCANADA (last visited June 23, 2016), http://www.keystone-xl.com/about/the-keystone-xl-oil-pipeline-project/; Amy Harder, Keystone XL Pipeline: From Application to Rejection, WALL ST. J. (Nov. 6, 2015), $\mathrm{http}: / /$ www.wsj.com/articles/keystone-xl-pipeline-from-application-to-rejection-1446847703. 
early 2017 encouraging approval of the pipeline ${ }^{12}$ - the decision to approve or reject Keystone XL does not affect economic output in the long run. If the State Department approves Keystone XL after President Trump's executive order, then the pipeline may be constructed. But the production associated with its construction is not "free." More spending increases demands on production, raising interest rates. With higher interest rates, some other spending projects no longer occur. The labor and capital employed to build the pipeline would likely be deployed in other settings even if the project is not approved. As long as "aggregate supply" capacity - determined by the size of the labor force, the capital stock, or technology-does not change, long-run economic output will not change. Even worse, if the pipeline was "inefficient" in the traditional law and economics sense-i.e., if the pipeline was not constructed, the labor force and other resources could have been used more productively elsewhere and the harm done to the environment by the pipeline would have been preventedthen approval would reduce effective output (including externalities).

In January 2012, by contrast, when the Obama administration initially declined to approve the Keystone pipeline application, ${ }^{13}$ interest rates were zero and employment rates very low - the classic indicators of a liquidity trap. In these conditions, approval of the Keystone XL project would have increased output and lowered unemployment. By enabling construction, approval would have increased aggregate demand. And at the zero lower bound, more aggregate demand causes more output and employment rather than shifting interest rates. As a result, approval of Keystone $\mathrm{XL}$ would have raised economic output in a liquidity trap. Due to the project's rejection by the Obama administration, however, the resources that would have been devoted to the construction of Keystone XL in 2012 instead sat idle. As such, approval or denial of the Keystone XL pipeline has time-varying economic effects. Variation in economic effects is not a function of the pipeline itself but rather of the prevailing economic condition at the time when a legal policy decision gets made.

\section{Laws Should Be Different at the Zero Lower Bound than in Other Times}

Traditional law and economics begins with a simple premise. Laws should be efficient, other things equal. Because laws are assumed to have timeinvariant economic effects, laws are either efficient or inefficient irrespective of the economic conditions. But if in reality the same law has different economic effects at different phases of the business cycle, then the same law may be

12. See Office of the Press Sec'y, Presidential Memorandum Regarding Construction of the Keystone XL Pipeline, WHITE HOUSE (Jan. 24, 2017), http://www.whitehouse.gov/the-pressoffice/2017/01/24/presidential-memorandum-regarding-construction-keystone-xl-pipeline.

13. See Office of the Press Sec'y, Statement by the President on the Keystone XL Pipeline, WHITE HOUSE (Jan. 18, 2012), http://obamawhitehouse.archives.gov/the-pressoffice/2012/01/18/statement-president-keystone-xl-pipeline. 
efficient at one point and inefficient at another time. If so, then the logic of law and economics predicates that the law should change as a function of the business cycle.

Because the economy functions differently at the zero lower bound than it does at other times, the effects of laws differ with the condition of the economy. Suppose, counterfactually, that the State Department approved the Keystone XL pipeline in 2012 but was debating whether to attach some safety and environmental conditions to its approval. The conditions would make the construction of pipeline more expensive and labor-intensive but would reduce the likelihood of spillage from the pipeline. Suppose further that, in ordinary economic times, the conditions are inefficient; the environmental benefits are smaller than the added cost.

At the zero lower bound, however, attaching the conditions may prove to be efficient. To comply with the conditions, the project would employ more workers and machines that would otherwise sit idle. This, in turn, would increase aggregate demand. The wages the workers receive as a result of the additional employment would also be spent, leading to a higher income for other people in the economy. This feedback loop would stimulate the economy and further increase aggregate demand. As a result, the true costs of the conditions to society are smaller than the direct costs, thanks to this "aggregate demand externality" of the conditions. A project that was inefficient in ordinary economic times may become efficient from a cost-benefit perspective at the zero lower bound.

As with Keystone $\mathrm{XL}$, so too with any legal decision that affects spending. What is efficient law changes with the business cycle. Accordingly, laws and legal rulings that promote spending (i.e., aggregate demand) should be favored in liquidity traps relative to other times.

Although this Kaldor-Hicks efficiency analysis prescribes business-cycle dependent law, ${ }^{14}$ the existing field of law and economics has almost never made such claims. ${ }^{15}$ In part, this is because law and economics has focused exclusively on the economics of ordinary times, and has ignored the economics of liquidity traps. From 1960 to 2008, a period without zero lower bound recessions in the U.S. or Europe, this exclusive focus made sense. ${ }^{16}$

Since the advent of the Great Recession in the late 2000s, however, the economics of zero lower bound recessions has become newly relevant. The Great Recession ruined countless lives, threatened political orders in the U.S. and the European Union, and cost the world economy tens of trillions of dollars

14. Indeed, the Hicks who first formulated the zero lower bound synthesis of Keynesian and Classical economics is the same Hicks who help formulate the "Kaldor-Hicks" definition of efficiency. See John R. Hicks (1904-1989), CONCISE ENCYCLOPEDIA ECON. (last visited on Aug. 3, 2017), http://www.econlib.org/library/Enc/bios/Hicks.html.

15. See infra Part I.

16. See infra figs. $3 \& 4$. 
in lost output. ${ }^{17}$ However, law and economics (outside from financial regulation ${ }^{18}$ ) has had almost nothing to say about the most important economic event of the last thirty years. This needs to change. Thus, this Article envisions a new field of law and macroeconomics that complements but differs from traditional law and (micro)economics.

One concern with this law and macroeconomic approach may be that, if law promotes aggregate demand during episodes of the zero lower bound such as the Great Recession, other goals of law-such as microeconomic efficiency, equity, or morality-may get compromised. In addition, lawyers have little macroeconomic expertise, so we may feel skeptical about their ability to diagnose the state of the business cycle and the macroeconomic effects of their decisions is uncertain. Thus, we may think that law should not be businesscycle-varying even if we buy the economic arguments in favor.

I disagree. The costs of doing (almost) nothing in liquidity traps are too catastrophic. If law can help mitigate these costs, then we need to seriously consider the remedies that law and macroeconomics can offer.

Moreover, many of these same arguments against law and macroeconomics also apply to conventional law and economics. Law inevitably gives up some equity when it pursues microeconomic efficiency, but that has not stopped law and microeconomics from flourishing. Furthermore, lawyers are ignorant about macroeconomics precisely because law schools do not teach them macroeconomics. The same thing could have been said (and still is said) about microeconomics, but this too has not held law and economics back. Indeed, teaching lawyers some macroeconomics would provide side benefits. If lawyers (as legislators, administrators, regulators, or judges) are to implement and adjudicate macroeconomically motivated policies, then they should understand why the policies were implemented in the first place.

There is also historical precedent for law and macroeconomics in practice. Indeed, at the U.S. regulatory level, law and macroeconomics predates the law and microeconomics we currently take for granted. For example, Inflation Impact Analysis, in which federal agencies evaluate the impact of major

17. See, e.g., Tyler Atkinson et al., How Bad Was It?: The Costs and Consequences of the 2007-09 Financial Crisis, DALlAS FED. RES. 1 (July 2013), http://dallasfed.org/assets/documents/research/staff/staff1301.pdf ("We conservatively estimate [the direct cost of the Recession in the U.S. to be] . . \$6 trillion to $\$ 14$ trillion); Sarah Childress, How Much Did the Financial Crisis Cost?, PBS (May 31, 2012), http://www.pbs.org/wgbh/frontline/article/howmuch-did-the-financial-crisis-cost; Jim Puzzanghera, Financial Crisis, Recession Cost U.S. 812.8 Trillion, Report Says, L.A. TIMES (Sept. 12, 2012), http://articles.latimes.com/2012/sep/12/business/lafi-financial-crisis-cost-20120913. As to Europe, see Loukas Tsoukalis, Steering Europe Out of the $\begin{array}{llllll}\text { Crisis, POL'Y NETWORK } & \text { PAPER } & 6 & \text { (2012), } & \text { http://www.policy- }\end{array}$ network.net/publications_download.aspx?ID=8201 ("Compared to the 5-year average trend, the slowdown of GDP growth rates since 2008 has led to an output loss of more than two trillion euro for EU-27 and more than one trillion for the Eurozone.").

18. See infra note 27 and accompanying text. 
regulations on inflation, ${ }^{19}$ predates the Cost-Benefit Analysis that forms the core of current economic analysis of new regulations. ${ }^{20}$

This Article is organized as follows. Part I describes the nascent literature on law and macroeconomics and shows that the purpose of this Article is to develop a general theory of law and macroeconomics that places these writings in a comprehensive economic framework. Part II examines the enormous costs of liquidity traps such as the Great Recession. Part III describes the economics of a liquidity trap in which interest rates remain at or near zero for an extended period, signaling inadequate aggregate demand. Part IV demonstrates how laws have business cycle varying economic effects, using the Keystone Pipeline approval debate and the debate about the choice of remedy in the celebrated contracts case of Jacob and Youngs $v$. Kent to provide two very different examples of the relevance of law and macroeconomics. Part $V$ argues that, at the zero lower bound on interest rates, law should be different because law's economic effects are different. In particular, law should encourage spending (i.e., stimulate aggregate demand). Part VI discusses, and partially rejects, some of the institutional competence arguments against business cycle varying law.

\section{Law and Macroeconomics: A Literature Review}

Before the advent of the Great Recession, very few articles considered law's varying economic effects over time. ${ }^{21}$ Kelman, in one of the few articles that considered law and macroeconomics, primarily asked why there was no law and macroeconomics rather than attempting to develop the field. ${ }^{22}$ Donohue and Seigelman demonstrated that macroeconomics affects employment-discrimination suits. ${ }^{23}$ Ramirez argued that much of the regulatory framework arising from the New Deal had overlooked macroeconomic

19. See Exec. Order No. 11,821, "Inflation Impact Statements," 39 Fed. Reg. 41,501

20. See Exec. Order No. 12,044, "Improving Government Regulations," 43 Fed. Reg. 12,661 (Mar. 24, 1978); Exec. Order 12,866, "Regulatory Planning and Review," 58 Fed. Reg. 51,735 (Oct. 4, 1993); Office of MGMT. \& Budget, EXeC. Office of the President, Circular A-4, "REGULATORY ANALYSIS" (Sept. http://www.whitehouse.gov/omb/assets/regulatory_matters_pdf/a-4.pdf.

21. "Law and Finance," also known as the "legal origins" literature, concerns the role of law in determining macroeconomic variables such as growth and the development of the financial sector. See, e.g., Edward L. Glaeser et al., Do Institutions Cause Growth?, 9 J. ECON. GrowTH 271 (2004); Rafael La Porta et al., The Economic Consequences of Legal Origins, 46 J. ECON. LitERATURE 285 (2008); Ross Levine, Law, Finance, and Economic Growth, 8 J. FIN. INTERMEDIATION 8 (1999). In addition to suffering from devastating empirical infirmities-see, e.g., Eric Helland \& Jonathan Klick, Legal Origins and Empirical Credibility, in DOES LAW MATTER? ON LAW AND ECONOMIC GROWTH 99 (Michael Faure \& Jan Smits eds., 2011)-this literature does not consider business cycles, which are the focus of this Article.

22. See Mark Kelman, Could Lawyers Stop Recessions? Speculations on Law and Macroeconomics, 45 STAN. L. REV. 1215 (1993); see also Douglas A. Kysar, Sustainability, Distribution, and the Macroeconomic Analysis of Law, 43 B.C. L. REV. 1 (2001) (using the term macroeconomics in a different sense than the papers described here).

23. See John Donohue \& Peter Siegelman, The Changing Nature of Employment Discrimination Litigation, 43 STAN. L. REV. 983 (1991). 
purposes. ${ }^{24}$ And more recently, after the Great Recession, Salama argued that lawyers should pay more attention to the "art" of macroeconomics rather than using the rigorous science of macroeconomics. ${ }^{25}$ While all of these papers engage with macroeconomic facts, none of them engage with macroeconomic theory or develop the analysis of law's time-varying economic effects.

Strnad provides a noteworthy exception, examining the macroeconomic impacts of different tax bases. ${ }^{26}$ Strnad, however, wrote before the Great Recession. Before the Great Recession of the late 2000 s, interest rates were unaffected by the zero lower bound. Strnad, for example, never mentions "liquidity trap" or the zero lower bound on interest rates, two concepts that form the core of this Article's emphasis on time-varying macroeconomics. Because the recessions (and inflation) of Strnad's experience were much more treatable than the liquidity traps that are the focus of this Article, Strnad's article does not discuss business-cycle-dependent legal policies.

Since the advent of the Great Recession, a number of articles have explored the interaction of law and macroeconomics. ${ }^{27}$ From 2009 to 2012, I wrote a number of papers discussing how tax law's countercyclical effects could be augmented, with a special emphasis on the destabilizing effects of tax expenditures. ${ }^{28}$ I also argued that all tax policies should be examined for their stabilizing or destabilizing effects on the business cycle as well as their effects

24. See Steven A. Ramirez, Law and Macroeconomics of the New Deal at 70, $62 \mathrm{MD}$. L. REV. 515 (2003).

25. See Bruno Meyerhof Salama, The Art of Law and Macroeconomics, 74 U. PITT. L. REV. 131, 164 (2012).

26. See Jeff Strnad, Some Macroeconomic Interactions with Tax Base Choice, 56 S.M.U. L. REV. 171 (2003).

27. In addition to articles implicitly exploring law and macroeconomics, a large and developing literature explores how to make financial regulation more robust so that banking crises, which often trigger liquidity traps can be avoided. See, e.g., ANAT ADMATI \& MARTIN HELLWIG, THE BANKERS' NEW ClOTHES (2014); Gary Gorton \& Andrew Metrick, Securitized Banking and the Run on Repo, 104 J. FIN. ECON. 425 (2012); Gary Gorton \& Andrew Metrick, The Federal Reserve and Panic Prevention: The Roles of Financial Regulation and Lender of Last Resort, 27 J. ECON. PERS. 45 (2013); Samuel G. Hanson, A Macroprudential Approach to Financial Regulation, 25 J. ECON. PERS. 3 (2011); Ross Levine, The Governance of Financial Regulation: Reform Lessons from the Recent Crisis, 12 INT'L REV. FIN. 39 (2011); Roberta Romano, For Diversity in the International Regulation of Financial Institutions: Critiquing and Recalibrating the Basel Architecture, 31 YALE J. ON REG. 1 (2014). These articles, however, do not consider how law should respond if the economy is already mired in a liquidity trap. While an ounce of prevention is worth a pound of cure, it is unrealistic to assume that any regulatory system could avoid periodic periods of excess unemployment and zero interest rates, which have occurred frequently in market economies throughout history. See, e.g., CHARLES P. KINDLEBERGER $\&$ Robert Z. AlibER, MANLAS, PANICS, AND CRASHeS 275-86 (5th ed. 2015).

28. See, e.g., Yair Listokin, A Note on Tax Expenditures and Business Cycle Fluctuations, 102 PROC. ANN. CONF. ON TAXATION 195 (2009); Yair Listokin, Stabilizing the Economy Through the Income Tax Code, 123 TAX NOTES 1575 (2009); Yair Listokin, Equity, Efficiency, and Stability: The Importance of Macroeconomics for Evaluating Income Tax Policy, 29 YALE J. ON REG. 45 (2012); Yair Listokin, How To Think About Income Tax When Interest Rates Are Zero, 151 TAX NOTES $959(2016)$. 
on microeconomic efficiency and equity. ${ }^{29}$ More recently, Masur and Posner have argued that Cost-Benefit Analysis should account for unemployment effects as well as direct costs. ${ }^{30}$ Zach Liscow has argued that bankruptcy law should pay more attention to job losses in recessions than in booms. ${ }^{31}$ Schwarcz has argued that law should change in response to changes in financial markets. ${ }^{32}$ Writing outside the law and economics perspective, economists Atif Mian and Amir Sufi have written a series of articles demonstrating that legal constraints, such as foreclosure laws, have important time-varying effects on consumption and employment. ${ }^{33}$

All of these papers make important contributions to the nascent field of "law and macroeconomics." But at the same time, they are all incomplete. Each focuses on a particular area of law, rather than asking if law has macroeconomic effects more generally. Even more importantly, the articles do not provide a strong theoretical argument for why law should be different at the zero lower bound than in other times, or explain why liquidity traps should be considered different from other recessions. Instead, they assume that law tries to be countercyclical at all times, ${ }^{34}$ focus on employment rather than macroeconomics, ${ }^{35}$ or assert that job loss causes more harm in recessions due to "reallocation problems" of uncertain origin. ${ }^{36}$

This Article, by contrast, uses the longstanding Hicksian synthesis between Keynesian and classical economics to argue that economies behave differently at the zero lower bound than at other times. As a result, every area of law has business-cycle-dependent effects. And if the economic effects of law help determine the right law, then laws should be different at the zero lower bound than in ordinary times.

One recent economics paper comes closest to my argument that law should be different based on macroeconomic conditions. Writing in the American Economic Review, Gauti Eggertsson provides an economic justification for many of the most contested regulatory interventions of the New Deal. Eggertsson explains:

29. See source cited in supra note 28; see also Brian D. Galle \& Jonathan Klick, Recessions and the Social Safety Net: The Alternative Minimum Tax as a Counter-Cyclical Fiscal Stabilizer, 63 STAN. L. REV. 187 (2010) (assessing the cyclical effects of the Alternative Minimum Tax).

30. See Jonathan S. Masur \& Eric A. Posner, Regulation, Unemployment, and CostBenefit Analysis, 98 VA. L. REV. 579 (2012).

31. See Zachary D. Liscow, Counter-Cyclical Bankruptcy Law: An Efficiency Argument for Employment-Preserving Bankruptcy Rules, 116 COLUM. L. REV. 1416 (2016).

32. See Steven L. Schwarcz, Changing Law to Address Changing Markets: A Consequence-Based Inquiry, 80 LAW \& CONTEMP. PROBS. 163-91 (2017).

33. See, e.g., Atif Mian, et al, Foreclosures, House Prices, and the Real Economy, 70 J. FIN. 2587 (2015); Atif Mian et al., Household Balance Sheets, Consumption, and the Economic Slump, 128 Q.J. ECON. 1687 (2013).

34. See sources cited in supra note 28 .

35. See Masur \& Posner, supra note 30.

36. See Liscow, supra note 31 , at 1470 ("Whether due to sticky information, sticky wages, or some other cause, reallocation does not work as well during recessions." (footnotes omitted)). 
Can government policies that reduce the natural level of output increase actual output? In other words, can policies that are contractionary according to the neoclassical model, be expansionary once the model is extended to include nominal frictions? For example, can facilitating monopoly pricing of firms and/or increasing the bargaining power of workers' unions increase output? Most economists would find the mere question absurd. This article, however, shows that the answer is yes under the special "emergency" conditions that apply when the short-term nominal interest rate is zero....

If even radical changes in law, like the suspension of antitrust laws, add to output at the zero lower bound, then surely the more moderate interventions proposed here, such as permitting a borderline project like Keystone at the zero lower bound, will prove even more efficient from a Kaldor-Hicks perspective.

\section{The Economic and Social Costs of the Great Recession}

The Great Recession of 2008-2016 imposed mind-bending costs to the economy and to political orders in the industrialized world. Even though the Great Recession appears to be over in the U.S. and Europe as of 2017-shortterm interest rates are above zero and employment rates are relatively highthe Great Recession's legacy lingers on in the form of permanently lower growth rates.

\section{A. Economic Costs}

A 2013 study by the Dallas Federal Reserve estimated that the Great Recession caused a cumulative loss of output of $\$ 6$ trillion to as much as $\$ 14$ trillion in the U.S. relative to potential output. ${ }^{38}$

Other regions suffered at least as much. The GDP of the Euro area did not return to its 2008 level of output until early 2016 (annual growth of 1\%-2\% used to be the norm) ${ }^{39}$ We can estimate the costs of the Great Recession in the Eurozone by looking at the output gap as measured by the OECD-the difference between potential GDP (determined by long-run aggregate supply) and actual output (determined by the interaction of aggregate demand and

37. Gauti Eggertsson, Was the New Deal Contractionary?, 102 AM. ECON. REV., 524,

38. See Luttrell et al., supra note 6. This is a 2013 estimate from the Dallas Federal Reserve Bank's Research Department. This figure represents two years' lost output. The wide range comes from uncertainty about the ultimate length of the Recession and likelihood of catch-up growth. The wide range is also caused by uncertainty about "hysteresis," discussed below on the next page.
39. See Peter S. Goodman, Europe's Economy, After 8-Year Detour, Is Fitfully Back
on
Track,
N.Y.
TIMES
(Apr.
29 ,
2016),
http://www.nytimes.com/2016/04/30/business/international/eurozone-economy-q 1 .html. 
supply). From 2009 to 2016, the cumulative output gap in the Eurozone was over $21 \%$ of GDP. ${ }^{40}$

The costs of the Great Recession were also distributed unequally. Those who lost their jobs suffered grievously, while those who kept their jobs suffered more modestly. Earnings inequality increased rapidly during the Great Recession. ${ }^{41}$ Thus, the staggering direct costs of the Great Recession may understate the true costs. The Great Recession exacerbated inequality while simultaneously hindering growth.

The costs of the Great Recession lingered into 2017. Indeed, the Great Recession appears to have permanently lowered growth rates in the U.S. Longterm unemployment increased markedly during the Great Recession. ${ }^{42}$ A long body of research demonstrates that long-term unemployment (more than one year) has particularly devastating effects. ${ }^{43}$ Someone who is unemployed for an extended period often leaves the labor force or accepts a job that does not take advantage of the worker's skills, permanently damaging growth prospects. Indeed, labor force participation rates in the U.S. dropped dramatically during the Great Recession. ${ }^{44}$ They have yet to fully recover.

Prolonged liquidity traps also affect preferences for risk-taking. One study finds that "individuals who have experienced low stock-market returns throughout their lives report lower willingness to take financial risk." 45 During the Financial Crisis of 2008 and the Great Recession, many investors experienced, or least witnessed, many risky investments lose money. If this experience has made them less likely to invest in promising but risky projects going forward, then the whole economy would suffer.

Liquidity traps thus appear to lower an economy's long-run potential output. Economists call this long-term shadow of a recession "hysteresis." If hysteresis effects are considerable, then the costs of recessions grow even

40. See Economic Outlook No 101-June 2017: Output Gaps: Deviations of Actual GDP from Potential GDP as \% of Potential GDP, OECD.STAT (last visited June 24, 2017), http://stats.oecd.org/Index.aspx?QueryId=51655. Some commentators argue that the OECD's output gap measurements understate the real size of the output gap.

41. See, e.g., Ben Casselman \& Andrew Flowers, Economic Inequality Continued To Rise in the U.S. After the Great Recession, FIVETHIRTYEIGHT (Sept. 4, 2014), http://fivethirtyeight.com/datalab/economic-inequality-continued-to-rise-in-the-u-s-after-the-greatrecession.

42. See Karen Kosanovich \& Eleni Theodossiou Sherman, Trends in Long-Term Unemployment, U.S. BUREAU LAB. STATS. (Mar. 2015), http://www.bls.gov/spotlight/2015/long-termunemployment/pdf/long-term-unemployment.pdf.

43. For a survey of this research, see Austin Nichols et al., Consequences of LongTerm Unemployment, URBAN INST. (Aug. 20, 2013), http://www.urban.org/research/publication/consequences-long-term-unemployment/view/full_report.

44. See United States Labor Force Participation Rate 1950-2017, TRADING ECON. (last visited June 25, 2017), http://radingeconomics.com/united-states/labor-force-participation-rate.

45. Ulrike Malendier \& Stefan Nagel, Depression Babies: Do Macroeconomic Experiences Affect Risk-Taking? (Nat'l Bureau of Econ. Research Working Paper No. 14813, 2009), http://www.nber.org/papers/w14813. 
greater. The upper range of the estimates for the costs of the Great Recession in the U.S. are so high because of hysteresis costs.

Recent research by Lawrence Summers, former Secretary of the U.S. Treasury, and others indicates that "secular stagnation" of industrialized economies in the aftermath of the Great Recession is an important concern. ${ }^{46}$ Growth rates in many developed economies have not returned to their preGreat Recession trends after the Great Recession "ended." Instead, growth rates look permanently lower. Estimates of potential long-run output in the U.S. and elsewhere have consistently been revised downwards, as the figures below indicate.

Figure 1: Downward Revision in Potential GDP, USA ${ }^{47}$

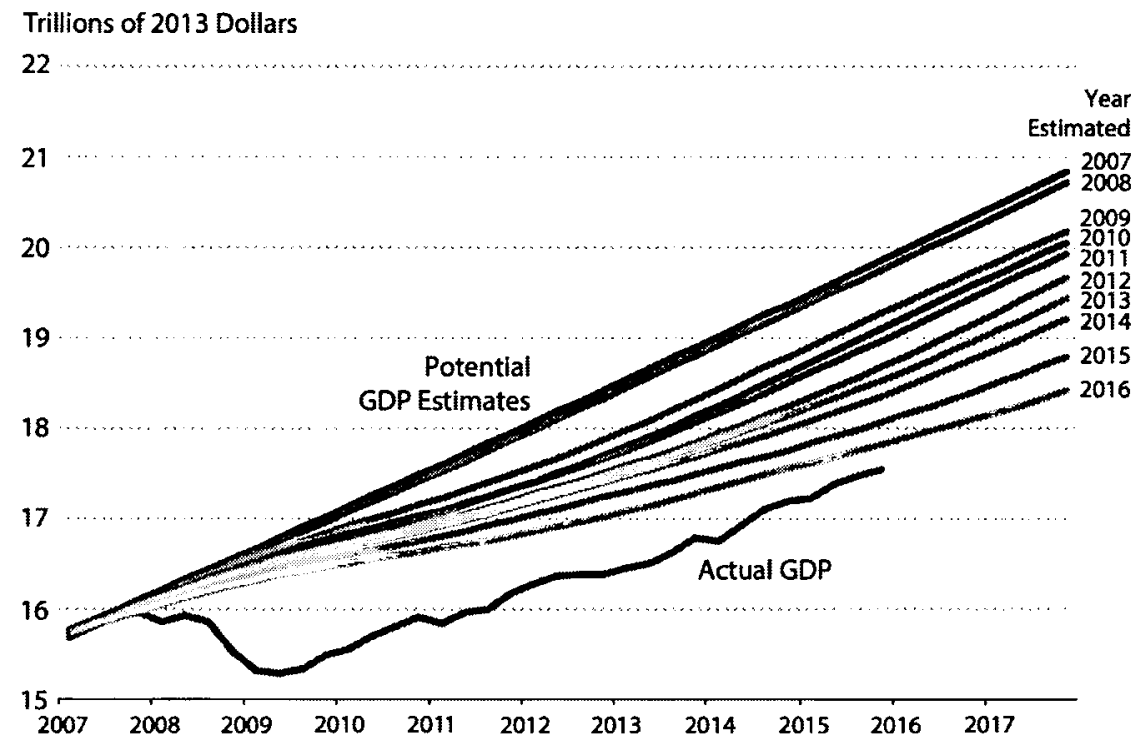

Note that estimates of potential GDP should be equally likely to be too high as too low. The consistent downward revision of potential GDP estimates in the U.S. and Eurozone reflect the fact that, post-Great Recession, growth rates have consistently disappointed relative to previous experience.

46. See, e.g., Lawrence H. Summers, U.S. Economic Prospects: Secular Stagnation, Hysteresis, and the Zero Lower Bound, 49 BUS. ECON. 65 (2014).

47. Lawrence H. Summer, Secular Stagnation and Monetary Policy, 98 FED. RES. BANK ST. LOUIS REV. 93, 94 fig.1 (2016). 
Figure 2: Downward Revision in Potential GDP, Eurozone ${ }^{48}$

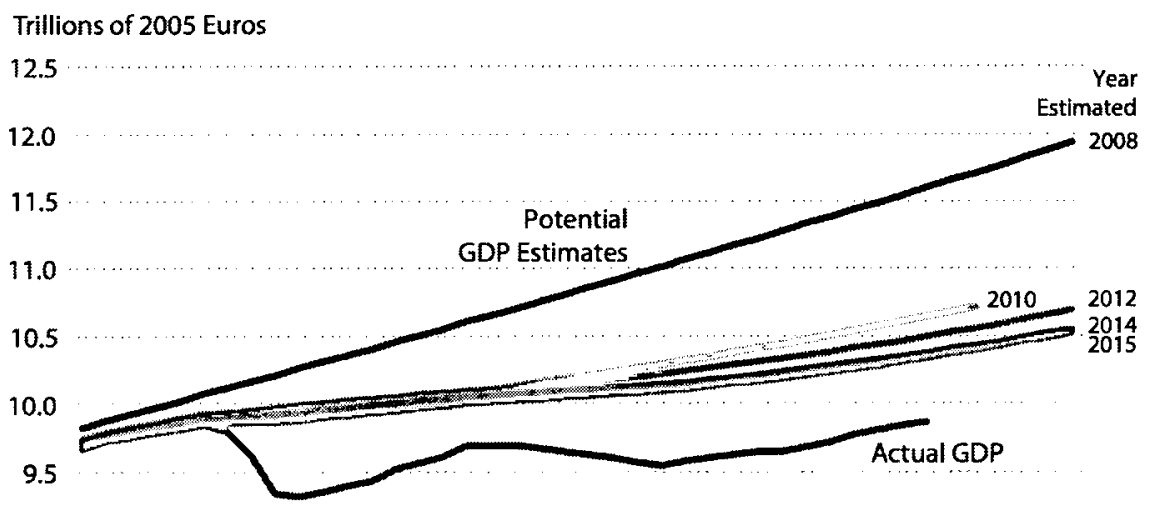

9.0

8.5

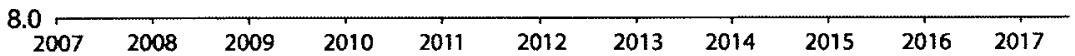

The economic costs of secular stagnation are staggering. If the U.S. had continued to grow at its "potential" rate as estimated in 2008 (the best estimate of output trends in 2008), then the U.S. economy would have produced $\$ 2.5$ trillion more in 2016 alone than it actually produced. With each passing year, this gap grows. If the Great Recession permanently lowered growth rates (and there is no compelling alternative explanation for a downward change in growth patterns occurring around 2008), then even a $\$ 14$ trillion cost may prove to be an underestimate. ${ }^{49}$

We can tell a similar story for the Eurozone. If the Eurozone had grown as forecasted, then it would have produced $€ 1.5$ trillion more in 2015 than it actually produced. The gap between the 2008 estimates and real output grows every year. Again, if the Great Recession is the cause of the persistent underperformance in the Eurozone, then the costs of the Great Recession in the Eurozone alone will be measured in many tens of trillions of Euros.

Not every economist subscribes to secular stagnation. Some, like Kenneth Rogoff, argue that the very slow growth experienced since 2008 is typical for economies recovering from the collapse of a debt bubble. ${ }^{50}$ Rogoff asserts that the current anemic growth predictions in the U.S. and Europe are too pessimistic; growth rates should recover once these economies repair their

48. Id. at 95 fig. 3 .

49. In a recent book, ROBERT J. GORDON, THE RISE AND FALL OF AMERICAN Growth: THE U.S. STANDARD OF LIVING SINCE THE CIVIL WAR (2016).

50. Kenneth Rogoff, Debt Supercycle, Not Secular Stagnation, in PROGRESS AND COnfusion: The STATE of MACROECONOMIC POLICY 19 (Blanchard et al. eds., 2016). 
balance sheets. For the purposes of law and macroeconomics, however, not much turns on the difference between secular stagnation and Rogoff's debt supercycle. Even if the Great Recession is just a "garden-variety" recovery from a financial crisis rather than the beginning of an indefinite period of subpar growth, the fact remains that inadequate demand associated with the debt collapse contributed to a staggering amount of lost output. Better monetary, fiscal, and legal policy might have mitigated the loss of output. Indeed, if the central cause of the Great Recession was too much debt, then law, which can adjust debt burdens directly, offers the best means of addressing the problem.

\section{B. Political Costs: Populism and the Great Recession}

Not only did the Great Recession pummel the economies of industrialized democracies, but it also undermined the social order of these countries. After the Great Recession, populism thrived in many Western democracies. In the U.S., Donald Trump garnered the Republican nomination in spite of rejecting many party orthodoxies (such as openness to immigration and trade). Trump then captured the presidency in November 2016. Whatever happens during the Trump presidency, most observers agree that his election is a dramatic break in the U.S. political order.

Populism also thrived in Europe in the aftermath of the Great Recession. The U.K. voted for Brexit, preferring national control over immigration and regulation to the continued free movement of goods, services, capital, and people throughout Europe. Populist challenges to the liberal order also grew stronger in many other European countries during the Great Recession.

The Great Recession did not singlehandedly cause the rise of populism, but prolonged liquidity traps and financial crises have raised the prospects of right wing populism. The Great Depression, for example, saw the rise of Nazism in Germany and fascism in many other countries. Indeed, a recent empirical study of Europe between 1870 and 2014 found that, after a crisis, "polarization rises ... voters seem to be particularly attracted to the political rhetoric of the extreme right, which often attributes blame to minorities or foreigners. On average, far-right parties increase their vote share by $30 \%$ after a financial crisis." 51

More than lost output appears to be at stake with macroeconomic policy. Deep macroeconomic recessions and depressions appear to threaten the very fabric of the social order.

If liquidity traps like the Great Recession cause harms of this magnitude, then we should be open to any policy that mitigates the harms - even if those

51. Manuel Funke et al., Going to Extremes: Politics After Financial Crises, 1870 2014, 88 EUR. ECON. REV. 227, 227 (2016). 
policies require sacrifices on other policy dimensions. The costs of simply allowing liquidity traps to run their course is enormous.

\section{The Economy Works One Way in Ordinary Economic Conditions and a Different Way in a Liquidity Trap}

An analogy to an individual market will give readers a better sense of why the economy functions differently at different times.

\section{A. The Restaurant Economy}

Consider the "market" for an individual restaurant. Assume that the restaurant's prices are fixed in the short and medium run. What determines the restaurant's output, or by analogy, what determines the size of the restaurant's economy?

It depends on how the restaurant is doing. If the restaurant is full-the restaurant "economy" is healthy -then supply capacity determines output. The restaurant has a ceiling on the number of meals it can produce because it only has so many seats, servers, ovens, etc. ${ }^{52}$ Suppose that the government decides to purchase (or mandate individual purchases of) meals in a full restaurant. The meals purchased or mandated by the government do not raise the restaurant's output; the restaurant is already producing all it can produce, so more demand does not mean more meals. Instead, the meals purchased by the government displace meals that would otherwise be consumed by private parties.

The full restaurant is analogous to an economy in ordinary circumstances. Output is not affected by increases in demand from government spending or other regulatory or legal interventions. Instead, output is determined by the restaurant's supply capacity. Legal interventions that affect demand for meals just move the restaurant's output from one place to another.

If law affects the supply capacity of the full restaurant (e.g., by allowing outdoor seating), then law changes output. This is the traditional vision of law and (micro)economics. Efficient laws would expand the supply capacity (subject to concerns about externalities) of the economy, enabling higher output. The impacts of law on demand for meals, rather than supply for meals, are irrelevant.

The analysis does not hold when the restaurant is operating below capacity, or when it is in "recession." Seats, servers, chefs, and ovens are underused. During these periods, the restaurant's output is not determined by its capacity. Rather, the restaurant's output is determined by the demand for

52. In reality, the output of meals may be a bit flexible even in a full restaurant. The restaurant can squeeze in more tables, or turn tables over faster. But, as a first approximation, it is not unreasonable to assume this way. 
meals. If more people come to the restaurant, then the restaurant produces more output.

In a recession, additional government spending on meals increases output, as the extra spending on meals fills empty tables. Likewise, a government mandate to buy meals in the restaurant also increases output by replacing empty tables with paying customers. ${ }^{53}$

In this illustrative restaurant "economy," laws thus have different effects in a recession than in ordinary times. In ordinary times, law's effects on demand for meals do not change output; they just redistribute it. Only law's effects on capacity matter for determining output. But in periods of inadequate demand for meals, law's effects on demand for meals can change output. A law that raises demand for meals raises output. A law that lowers demand for meals lowers output. The effects of a law thus depends on the state of the business cycle. Law and economics must take these effects into account.

\section{$B$. Interest Rates and the Restaurant Economy}

To this point, the analogy has ignored the savings and borrowing market. This savings and borrowing market brings aggregate demand back into balance with capacity when there is inadequate or excess aggregate demand. People who earn more than they spend on meals can lend money to people who want to spend more on meals than they currently earn. The interest rate represents the price that borrowers pay to savers in order to use the savers' money. If the restaurant is empty even though meals are the only thing people can buy, then this means that there are excess savings. In response, interest rates, which are the price of borrowing money, go down. The decrease in interest rates makes savings less attractive and buying meals more attractive. With interest rates lower, more people buy meals rather than save, bringing aggregate demand for meals back into balance with the restaurant's capacity.

If interest rate adjustment brought demand for meals into balance with the restaurant's capacity instantaneously, then output would always equal capacity - a condition known as Say's Law. But Say's Law is a fallacy. ${ }^{54}$ When demand falls short of the restaurant's capacity, it will take a while before a decrease in interest rates raises aggregate demand enough to make up for the shortfall. This temporary period of production below the restaurant's capacity is a recession.

53. In a perfect world, a government mandate to spend money on restaurant meals would be misguided. People may not want the meals very much. If the economy is operating at capacity, a meals mandate would thus be a bad thing. It reshuffles meals towards some who do not value them much. But if the restaurant has spare capacity, then the meals mandate may not be inefficient. So long as the people who are compelled to buy the meals value the meals more than the very small cost of producing the meals when there is spare capacity, then the meals mandate would be efficient when output is constrained by demand.

54. See, e.g., Paul Krugman, Still Say's Law After All These Years, N.Y. TimEs (Feb. 10, 2013), http://krugman.blogs.nytimes.com/2013/02/10/still-says-law-after-all-these-years. 
Even if the savings market does not eliminate recessions in the restaurant economy, it mitigates recessions' length and severity. Over time, the changes in interest rates prompted by recessions should bring aggregate demand back into balance with the restaurant's supply capacity, ending the recession. And if the central bank controls the money supply, then it can adjust the money supply to hasten the changes in interest rates that bring aggregate demand back into balance with supply.

So long as the interest rate is equilibrating the market for savings, recessions will be temporary. In order for public policy to hasten the end of a temporary recession, the policy must be nimble and run by experts. This might describe the central bank's use of monetary policy, but it does not describe the law. If law cannot effectively mitigate recessions, then it makes sense for law to ignore aggregate demand. If the interest rate is doing its job of equilibrating the savings market, then law and microeconomics, which ignores the effects of a law on the demand for meals, gives a reasonable approximation for the economic effects of laws.

\section{Macroeconomic Conditions at the Zero Lower Bound on Interest Rates}

Interest rates, however, do not always serve their economic equilibrating function of balancing investment and savings. Suppose that people become extremely nervous about spending and that literally everyone wants to save. In order to balance savings and investment, the interest rate would need to be negative so that some people will invest or consume rather than save. But the interest rate cannot be negative-a condition known as the zero lower bound on interest rates. Nominal interest rates cannot fall (much) below zero because individuals would hoard cash (which earns a zero rate of return) rather than lending their savings to borrowers who pay negative interest rates. ${ }^{55}$

Because of the zero lower bound on interest rates, the interest rate alone may not equilibrate savings and investment. At the zero lower bound, savings sits around as cash rather than getting spent by someone else. At the zero lower bound, a shortage of spending on restaurant meals does not get offset by a decrease in interest rates that allows borrowers to borrow more and buy more

55. A nominal interest rate is the interest rate expressed without regard to inflation. There is no hard rule that prevents interest rates from going below zero. In early 2016 , for example, short-term interest rates were (slightly) below zero in the Eurozone, Switzerland, Sweden, and Denmark. See European Short Term Interest Rates Report, YCHARTS (last visited June 25, 2016), http://ycharts.com/indicators/reports/european_short term interest rates. How could this happen? Putting cash in a safe place is costly, and savers may be willing to pay a small fee (a negative interest rate) in order to keep their money in government bonds. If the interest rate goes well below zero (at present, the lowest rate in any country is approximately $-1 \%$ ), then we would expect significant distortions to behavior, such as widespread cash hoarding and prepayment of costs. Even if the zero lower bound is not literally binding, it proves to be a useful approximation. For a discussion of the theoretical causes and implications of negative short term interest rates, see Matthew Rognlie, What Lower Bound? Monetary Policy with Negative Interest Rates (unpublished manuscript) (2016), http://economics.mit.edu/files/11174. 
meals. Instead, people continue to save rather than spend. Potential output thus exceeds consumption and investment, and there can be general excess supply. This is the liquidity trap. The capacity glut can continue indefinitely because there is no longer an effective equilibrating mechanism to bring aggregate demand back into balance with capacity.

An economy stuck at the zero lower bound is a different economy than an economy with an interest rate free to fluctuate. Demand for meals with nominal interest rates of zero can persistently fall short of capacity. More spending in the economy at the zero lower bound leads to more output by utilizing slack capacity rather than raising interest rates and reshuffling output.

Figure 3 shows extremely short-term interest rates in the U.S., U.K., Japan, and Eurozone. Central banks directly set these rates, and use them to indirectly influence longer-term rates. ${ }^{56}$ Figure 3 demonstrates that between the mid-1970s and the mid-1990s, interest rates were consistently above zero in all four regions. In the mid-1990s, Japanese rates struck the zero lower bound on interest rates, and have remained at zero ever since. Japan's zero short-term interest rates coincided with the "lost decade"-actually, two decades-in which the Japanese economy has consistently fallen short of expectations. ${ }^{57}$

Zero interest rates seemed to be a uniquely Japanese phenomenon until the advent of the Great Recession in 2008-09. During the Great Recession, short-term interest rates plummeted to zero in every economy in the chart. They stayed near zero through late 2015 or afterwards. In addition, labor force participation rates declined dramatically and economic growth rates also slid significantly in the U.S., U.K., and Eurozone.

56. Indeed, zero short term interest rates are often associated with very low (or even negative) yields on long term bonds. On June 14, 2016, for example, ten year government borrowing rates were $1.61 \%$ in the U.S., $1.14 \%$ in the UK, $-.18 \%$ in Japan, and $-.01 \%$ in Germany. See Government Bond IOy - Countries - List, TRADING ECON. (last visited June 14, 2016), http://www.tradingeconomics.com/bonds.

$$
\begin{array}{llllll}
\multicolumn{4}{c}{57 .} & \text { See Naohisa Hirakata et al., Japan's Financial Crises and Lost Decades 2-3 (Fed. } \\
\text { Res. } & \text { Bank } & \text { Dallas } & \text { Working Paper } & \text { No. } & \text { 220), } \\
\text { http://www.dallasfed.org/assets/documents/institute/wpapers/2014/0220.pdf. } & &
\end{array}
$$


Figure 3: Short-Term Interest Rates in the U.S., U.K., Japan, and Eurozone ${ }^{58}$

\section{$=0200$ - Immediate Rates: Less than 24 Hours: Call Money/Interbank Rate for the United States $($ ) \\ - Immediate Rates: Less than 24 Hours: Call Money/Interbank Rate for the United Kingdom 0 \\ - Immediate Rates: Less than 24 Hours: Central Bank Rates for Japan $\theta$ \\ ... Immediate Rates: Less than 24 Hours: Call Money/Interbank Rate for the Euro Area(c)}

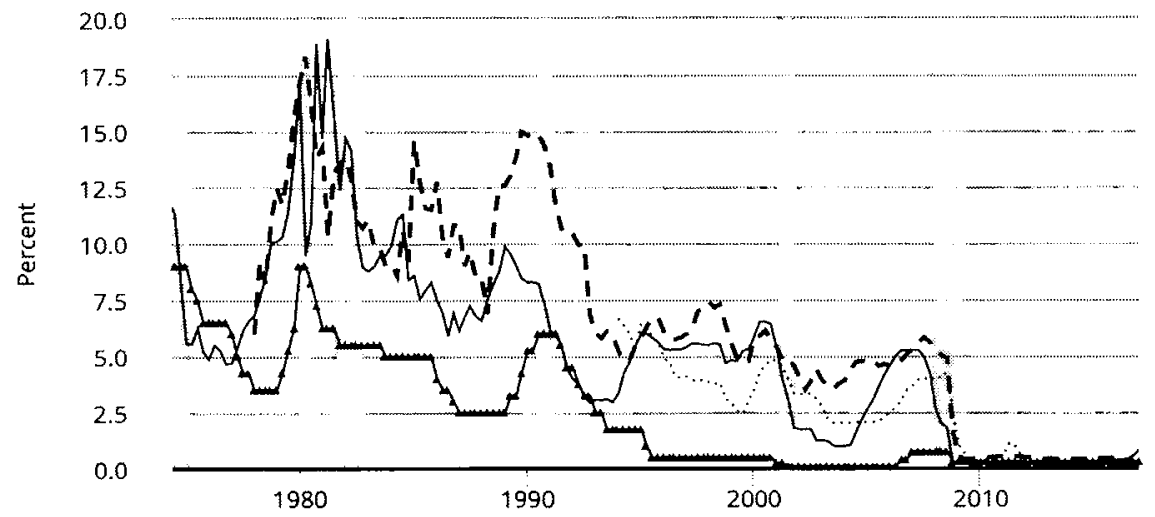

Source: Organization for Economic Co-operation and Development fred.stlouisfed.org

myf.red/g/eezb

Liquidity traps are not synonymous with recessions. In the U.S., recessions are defined as two consecutive quarters of negative GDP growth. ${ }^{59}$ Figure 3 indicates U.S. recessions by shading the corresponding time periods in gray.

For every post-World War II U.S. recession before 2008, interest rates remained well above zero. In ordinary recessions, the interest rate continues to perform its equilibrating role. In ordinary recessions, there is a fall in desired spending and output that is offset in relatively short order by a decrease in interest rates, which, in turn, leads to more consumption and investment. As a result, the economy enjoys a self-correcting mechanism - the interest rate-that prevents the economy from staying below capacity for a period of years. And when post World War II ordinary recessions ended, they truly ended: for

58. This is a custom-made graph from FRED Economic Data, FED. RES. BANK ST. LouIS (last visited June 26,2016 ), http://fred.stlouisfed.org/graph/?id=IRSTCI01GBQ156N,IRSTCI01EZQ156N,IRSTCI01USQ156N,IRS TCB01JPQ156N,\#0.

59. See Recession: How Is that Defined? BuREAU ECON. ANALYsIS (March 31, 2008), http://www.bea.gov/faq/index.cfm?faq_id=485. 
instance, U.S. economic growth returned to its trend rate after the recession ended. $^{60}$

Not so when interest rates hit the zero lower bound. Because the interest rate cannot decrease below zero to reduce savings and spur investment, the economy loses its primary equilibrating mechanism. As a result, zero lower bound recessions tend to be associated with prolonged periods of economic torpor and social dislocation. ${ }^{61}$

Over the last eighty years, the only two periods in which short-term interest rates hit the zero lower bound in the U.S. were the Great Depression and the Great Recession. Both of these episodes lasted for years and caused much greater harms than the much shorter and milder recessions that characterized the intervening periods. Figure 4 presents short-term U.S. interest rates (three month treasury borrowing rates) from 1934 to the end of 2016.

Figure 4: 3-Month Treasury Bill, Secondary Market Rate ${ }^{62}$

FRED $\quad$ - 3-Month Treasury Bill: Secondary Market Rate

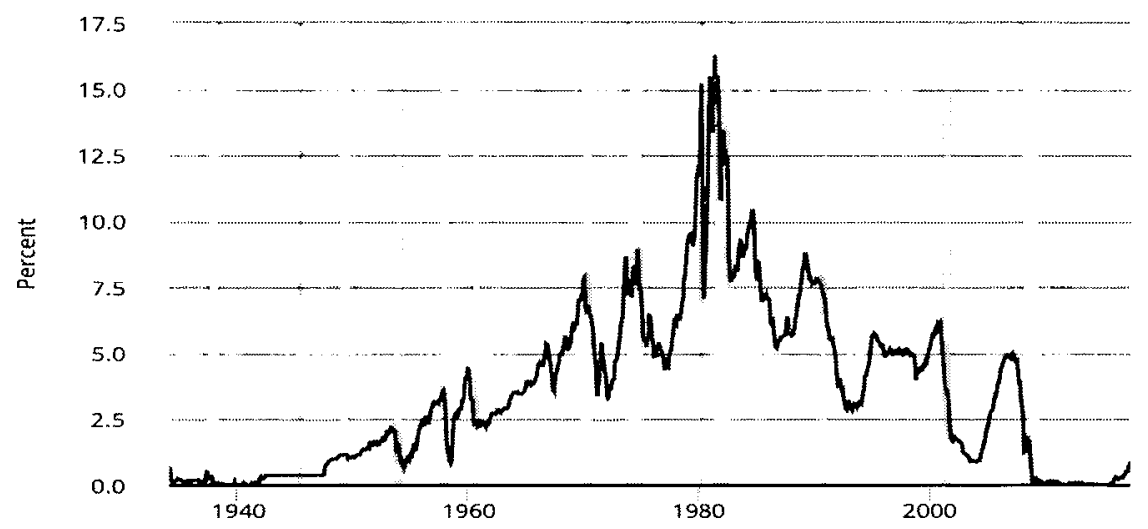

Source: Board of Governors of the Federal Reserve System (US) fred.stlouisfed.org

myf.red/g/eezz

60. See United States GDP Growth Rate, TRADING ECON. (last visited June 26, 2016).

61. See, e.g., Francisco Buera \& Juan Pablo Nicolini, Liquidity Traps and Monetary Policy: Managing a Credit Crunch, FED. RES. BANK MINNEAPOLIS 40-41 (July 2014), http://www.minneapolisfed.org/research/wp/wp714.pdf ("There is a side effect of the policies that avoid deflation]: they generate slow recovery. We argue that many of the features of the model capture the characteristics of the last financial crisis that hit the United States starting in 2008 and the one that hit Japan in the early 1990 s ... . The model of this paper implies that avoiding the zero bound or not implies nontrivial trade-offs: ameliorating the drop in output at the cost of a slower recovery."); Stephanie Schmitt-Grohe \& Martin Uribe, Liquidity Traps and Jobless Recoveries, 9 AM. ECON. J.: MACROECON. 165, 165 (2017) ("As in Europe and the United States, the jobless growth recovery [in Japan] took place in the context of zero nominal rates and declining rates of inflation."); Pablo CubaBorda, What Explains the Great Recession and the Slow Recovery? 1-2 (unpublished manuscript, 2014), http://econweb.umd.edu/ cuba/PCB-JMP.pdf.

62. This is a custom-made graph from FRED Economic Data, FED. RES. BANK ST. LOUIS (last visited January 30, 2017), http://fred.stlouisfed.org/series/TB3MS\#0. 
In addition, the zero lower bound episodes that I emphasize in this Article are not always formally defined as recessions. In the U.S. from 2010 to 2015 or from 1934 to 1937, for example, short-term interest rates were approximately zero, labor force participation rates very low, and output growth rates anemic. ${ }^{63}$ These economies would qualify as experiencing a liquidity trap. They would not, however, qualify as a recession as traditionally defined because the U.S. economy's output was not actually shrinking for two consecutive quarters ${ }^{64}$ (in Figure 4, traditionally defined U.S. recessions are shaded gray).

As Figures 3 and 4 demonstrate, it is unusual for interest rates to be constrained by the zero lower bound, but the length of the economic stagnation and the magnitude of harm due to the zero lower bound are longer and larger than those in ordinary recessions. In the U.S., for example, short-term interest remained significantly above zero from the early 1940 s to 2008 (Figure 4). ${ }^{65}$ When short-term interest rates hit zero, however, they can remain there for extended periods of time and cause great harm, as the Great Recession and Great Depression attest. And episodes of zero interest rates can last even longer than the 10-plus year duration of the Great Depression. Japan, for example, has been coping with the zero lower bound on interest rates for more than twenty years. ${ }^{66}$ Relative to its previous performance, Japan's economy has been moribund for the entire period it has been at the zero lower bound, costing trillions of dollars. ${ }^{67}$

63. See United States Labor Force Participation Rate, TRADING ECON. (last visited June 26, 2016), http://www.tradingeconomics.com/united-states/labor-force-participation-rate; United States GDP Growth Rate, TRADING ECON. (last visited June 26, 2016), http://www.tradingeconomics.com/united-states/gdp-growth; United States Fed Funds Rate, TRADING ECON. (last visited June 26, 2016), http://www.tradingeconomics.com/united-states/interest-rate.

64. See supra note 59 and accompanying text.

65. See James Clouse et al., Monetary Policy When the Nominal Short-Term Interest Rate Is Zero, FED. RES. 7 fig.2.1 (Nov. 27, 2000).

66. See Leika Kihara, Japan Eyes End to Decades Long Deflation, REUTERS (Aug. 17, 2012), http://www.reuters.com/article/japan-economy-estimate-idUSL4E8JH1TC20120817 (referring to the lost decade as "a corrosive mix of falling prices and weak economic growth for much of the past two decades"); James Rickards, Japan's (Third) Lost Decade, D. RECKONING (May 13, 2015), http://dailyreckoning.com/japans-third-lost-decade ("Today, a full 25 years after the bubble burst in Japan, that country continues to struggle with deflation, zero interest rates, weak banks, adverse demographics, and periodic bouts of negative growth. Japan has endured a 25 year depression, and there is no end in sight.").

67. Over the period from 1995 to 2007 , Japan's GDP fell from $\$ 5.33$ to $\$ 4.36$ trillion dollars in nominal terms, and its real wages fell around 5\%. See Gross Domestic Product, Google (last visited June 26, 2016), http://www.google.ae/publicdata/explore?ds=d5bncppjof8f9_\&met_y=ny_gdp_mktp_cd\&hl=en\&dl=en

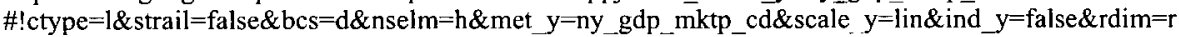
egion\&idim=country:JPN\&ifdim=region\&hl=en_US\&dl=en\&ind=false. Considering the growth in GDP that the Japanese economy could have had based on its growth rate prior to the beginning of the lost decade, the harm to its economy is even bigger than the $\$ 1$ trillion noted above. In particular, Brad DeLong commented "Japan is now 40 to 50 percent below what the world in 1991 would have estimated their GDP to be in 2012," and this gap in the prediction and the actual GDP size amounts to a couple of trillions. Brad DeLong, A Question from the Floor: Understanding Japan's Options in the Early 1990s, 
Looking forward, the zero lower bound problem is likely to become more prevalent. A 2017 paper from two economists at the Federal Reserve estimates that, under plausible assumptions "the [Zero Lower Bound] binds two-fifths of the time." As a result, the alternative macroeconomic state that I emphasize here is likely to be the most relevant one for many important legal decisions.

\section{Why the Economy Functions Differently in Zero Lower Bound Recessions Than at Other Times}

Why does the economy function differently in zero lower bound recessions than at other times? I will provide two related answers, followed by a more rigorous exposition of those two answers through the IS-LM model. ${ }^{68}$

\section{The Interest Rate Does Not Equilibrate Capacity and Aggregate Demand}

We have already described one answer. At the zero lower bound in interest rates, supply and demand for investment are not equilibrated by the interest rate. A lack of demand in goods is not replaced by more demand in investment or more consumption. Unlike in ordinary economic times, the economy loses an important equilibrating mechanism. According to Summers, "Secular stagnation occurs when neutral real interest rates are sufficiently low that they cannot be achieved through conventional central-bank policies. At that point, desired levels of saving exceed desired levels of investment, leading to shortfalls in demand and stunted growth."69

We will explore this answer in more detail below in our discussion of the zero lower bound liquidity trap and the IS-LM model. ${ }^{70}$

\section{Inefficacy of Monetary Policy}

Interest rates of zero do not just deprive the economy of an important selfequilibrating mechanism. They also deprive policymakers of their primary tool for stabilizing economies: monetary policy. ${ }^{71}$ Central banks directly control

BRADFORD-DELONG.COM (Aug. 1, 2012), http://delong.typepad.com/sdj/2012/08/a-question-from-thefloor-understanding-japans-options-in-the-early-1990s.html.

68. For more sophisticated macro theory arguments that the economy (and in particular fiscal policy) functions differently at the zero lower bound than at other times, see, for example, Lawrence Christiano et al., When Is the Government Spending Multiplier Large?, 119 J. POL. ECON. 78 (2011); Gauti B. Eggertsson, What Fiscal Policy Is Effective at Zero Interest Rates?, 25 NBER MACROECON. ANN. 59 (2011); and Michael Woodford, Simple Analytics of the Government Expenditure Multiplier, 3 AM. ECON. J.: MACROECON. 1 (2011).

69. See Larry Summers, The Age of Secular Stagnation: What It Is and What To Do About It, FOREIGN AFF. (Mar./Apr. 2016), http://www.foreignaffairs.com/articles/united-states/2016-0215/age-secular-stagnation.

70. See infra Section III.E.

71. Before the Great Recession, there was a consensus among economists that monetary policy was the only tool that should be used to mitigate recessions and booms. See, e.g., John 
very short-term interest rates and the money supply. ${ }^{72}$ Indirectly, this control mechanism gives central banks power to influence long-term interest rates. ${ }^{73}$ When aggregate demand is inadequate and inflation falls below target rates, central banks conduct expansionary monetary policy (bringing down interest rates) to stimulate the economy. On the other hand, when aggregate demand is too high and begins to cause inflation, central banks conduct contractionary monetary policy (raising up interest rates) to offset the undesirable inflationary impulses.

When constrained by the zero lower bound on interest rates, however, monetary policy loses its effectiveness. ${ }^{75}$ Even when an economy needs expansionary monetary policy to boost aggregate demand, central banks cannot lower interest rates any further. In ordinary recessions, a central bank that wants to stimulate the economy lowers interest rates. At the zero lower bound, this is not an option. Zero lower bound recessions are thus different from ordinary recessions. While a central bank can turn to "unconventional monetary policy" such as quantitative easing, ${ }^{76}$ such policies are, by definition,

B. Taylor, Reassessing Discretionary Fiscal Policy, 14 J. ECON. PersP. 21, 34-35 (2008) (describing consensus in favor of rejecting discretionary fiscal policy).

72. See Monetary Policy and Central Banking, INT'L MON. Fund (Mar. 31, 2016), http:/www.imf.org/external/np/exr/facts/mpcb.htm.

73. Id.

74. The true costs of inflation are hotly debated. Some argue that these costs have been overstated and that some inflation (e.g., 4\% a year) is a good thing. See, e.g., Jonathan Chiu \& Miguel Molico, Liquidity, Redistribution, and the Welfare Cost of Inflation, 57 J. MONETARY ECON. 428, 428 (2010); Stanley Fischer, Towards an Understanding of the Costs of Inflation: II, 15 CARNEGIEROCHESTER CONF. SERIES PUB. POL'Y 5, 5 (1981); Robert E. Lucas, Discussion of: Stanley Fischer, "Towards an Understanding of the Costs of Inflation II," 15 CARNEGIE-ROCHESTER CONF. SERIES PUB. POL'Y 43, 43 (1981); Laurence Ball, The Case for 4\% Inflation, VoX (May 24, 2013), $\mathrm{http} / / \mathrm{www}$.voxeu.org/article/case-4-inflation. Others argue that costs have been understated and they have welfare consequences. See, e.g., Michael Dotsey \& Peter Ireland, The Welfare Cost of Inflation in General Equilibrium, 37 J. MONETARY ECON. 29, 29 (1996); Tim Worstall, No, We Don't Want to Move to $a$ Inflation Target, ForBES (Sep. 27, 2014), http:/www.forbes.com/sites/timworstall/2014/09/27/no-we-dont-want-to-move-to-a-4-inflation-

target/\#35dd3c8e6040. Whatever opinion one holds, the fact remains that most central banks are charged with maintaining some form of price stability. A central bank has a statutory obligation to constrain the economy if inflation begins to rise: for instance, the Federal Reserve Act charges the Federal Reserve of the U.S. to seek "stable prices" among various objectives, 12 U.S.C. $§ 225$ (a) (2012), and the European Central Bank's primary mandate is "to maintain price stability," Consolidated Version of the Treaty on the Functioning of the European Union art. 127 I 1, Oct. 26, 2012, 2012 O.J. (C 326) 47.

75. In addition, because central banks are neutered by the zero lower bound, the economic effects of fiscal policies are different at the zero lower bound than they would be at other interest rates. During ordinary times with positive short-term interest rates, a fiscal stimulus raises inflationary pressures. The central bank will respond by raising interest rates, bringing output back to its expected level. During a zero lower bound recession, by contrast, the central bank cannot-and does not want to - offset fiscal stimulus. Fiscal stimulus raises aggregate demand, which is exactly what the central bank would have done with monetary policy if the central bank were not constrained by the zero lower bound. At the zero lower bound, the central bank is not worried about inflation because the economy has a lot of slack capacity that holds back inflationary tendencies. As a result, the central bank fully accommodates the increase in aggregate demand the fiscal policy is doing what the central bank would like to do, but can't. Fiscal policy thus increases output at the zero lower bound.

76. For more information on quantitative easing, see infra 164 and accompanying text 
experimental, and have proven to be only slightly effective. ${ }^{77}$ Furthermore, quantitative easing policies can lead to other unexpected, undesirable outcomes such as the devaluation of currency, inflations, asset price bubbles, and so forth. $^{78}$

\section{E. IS-LM and the Zero Lower Bound}

In this Section, I will provide a more rigorous version of the previous two answers as to why the economy functions differently in zero lower bound recessions. Readers who wish to avoid more technical economics should feel free to skip over this discussion. They will lose rigor and analytic clarity, but save time and remain able to fully engage with the remainder of the article.

\section{IS-LM}

We can make these arguments more rigorous by adopting the Hicksian ISLM model that forms the starting point for modern Keynesian economics. ${ }^{79}$ I will describe the IS/LM model in some detail. Although this is analogous to explaining supply and demand from first principles in a conventional law and economics article (supply and demand and IS/LM make up the bulk of first year college economics courses), I provide the extra explanation because

77. See, e.g., Victor Lyonnet \& Richard Werner, Lessons from the Bank of England on 'Quantitative Easing' and Other 'Unconventional' Monetary Policies, 25 INT'L REV. FIN. ANALYSIS 94, 94 (2012) ("The empirical analysis indicates that QE as defined and announced in March 2009 had no apparent effect on the UK economy."); Hiroshi Ugai, Effects of the Quantitative Easing Policy: A Survey of Empirical Analyses, 25 MON. \& ECON. STUD. JAPAN 1, 1 (2007) ("The QEP's effect on raising aggregate demand and prices was often limited."). But see, e.g., Arvind Krishnamurthy \& Annette Vissing-Jorgensen, The Effects of Quantitative Easing on Interest Rates: Channels and Implications for Policy, Fall 2011 BROOKINGS PAPERS ON ECON. ACTIVITY 215, 215 ("There is significant evidence that QE policies can alter long-term interest rates.").

78. See, e.g., Daniel L. Thornton, The Downside of Quantitative Easing, 34 FED. RES. BANK ST. LOUIS ECON. SYNOPSES 1, 1-2 http://research.stlouisfed.org/publications/es/10/ES1034.pdf; Jennifer Ablan, Fed Easing May Mean 20 Percent Dollar Drop: Gross, REUTERS (Nov. 1., 2010), http://www.reuters.com/article/us-pimco-grossidUSTRE6A055R20101101; Philip Aldrick, The Case for and Against Quantitative Easing, TELEGRAPH (Oct. 2011), http://www.telegraph.co.uk/finance/personalfinance/interest-rates/8810763/The-case-forand-against-quantitative-easing.html.

79. Since the critique of the real business cycle theorists in the $1970 \mathrm{~s}$ and $1980 \mathrm{~s}$, see, for example, Finn E. Kydland \& Edward C. Prescott, Time to Build and Aggregate Fluctuations, 50 ECONOMETRICA 1345 (1982); Robert E. Lucas, Expectations and the Neutrality of Money, 4 J. ECON. THEORY 102 (1972); Robert Lucas, Econometric Policy Evaluation, in THE PHILLIPS CURVE AND LABOR MARKETS 19 (Karl Brunner \& Allan H. Meltzer eds., 1976); Robert E. Lucas, Some International Evidence on Output-Inflation Tradeoffs, 63 AM. ECON. REV. 326 (1973); Robert E. Lucas \& Leonard A. Rapping, Real Wages, Employment, and Inflation, 77 J. POL. ECON. 721 (1969); Thomas J. Sargent \& Neil Wallace, 'Rational' Expectations, the Optimal Monetary Instrument, and the Optimal Money Supply Rule, 83 J. POL. ECON. 241 (1975). The Keynesian IS-LM model has been augmented by more sophisticated neo-Keynesian models. See, e.g., MICHAEL WOODFORD, MONEY, INTEREST, AND PRICES 9-10, 139-236 (2003). Neo-Keynesian models derive similar conclusions to the IS-LM model, but derive these conclusions from microfoundations rather than the more ad-hoc assumptions of Hicks and Keynes. IS-LM is still featured in most macroeconomics textbooks and is the framework within which many macroeconomic policymakers make their decisions. 
macroeconomics is likely to be less familiar to readers of a legal bent than microeconomics.

- We start with the two roles played by the interest rate. ${ }^{80}$ First, as emphasized above, the interest rate equilibrates the amount of savings with the desired amount of investment. This role leads to the investment-savings ("IS") equation. ${ }^{81}$ Second, the interest rate ensures that the demand for liquid assets (e.g., cash) in contrast to illiquid assets (e.g., bonds) equals the supply of liquid assets - the amount of cash in the economy. This is the liquidity-money ("LM") equation. $^{82}$

The interest rate-a single variable - cannot alone solve two different equations. As a result, the interest rate, functioning alone, cannot guarantee that both of these markets are in equilibrium. Instead, interest rates and output move jointly to equilibrate the two markets. ${ }^{83}$ Reflecting this idea, the IS and the LM equations are mapped onto the grid of the $\mathrm{x}$-axis as income/economic output $Y$ and the $y$-axis as the interest rate $i$.

Let us first consider the IS market. The IS curve displays the set of points at which the demand for investment equals the supply of savings. Savings increase with output, because more output in the economy means generally more income for people in the economy, who in turn increase their savings. People tend to save a consistent fraction of their income. ${ }^{84}$ For an increased amount of the supply of savings to be spent, investment needs to increase, which requires interest rates to go down. Thus, for the investment-savings market to be in balance, more investment/output is associated with lower interest rates. That is, the IS curve is downward sloping; lower interest rates correspond to higher levels of output. ${ }^{85}$

Consider some combination of interest rate and output, such as Point $A$ in Figure 5. Savings exceeds investment at Point $A$. The IS market is out of equilibrium. In order to bring savings and investment into balance, output and/or the interest rate must decrease. Suppose that we want to bring the

80. This discussion follows Nobel Prize winning economist Paul Krugman's lucid explanation of the Hicksian IS-LM model for readers unfamiliar with economics. See Paul Krugman, ISLMentary, N.Y. Times (Oct. 9, 2011), http://krugman.blogs.nytimes.com/2011/10/09/is-lmentary/ [hereinafter $I S$-LMentary]. For an explanation of the three good general equilibrium foundations of the IS-LM, which make the theory more useful than most would appreciate, see Paul Krugman, There's Something About Macro (last visited June 27, 2016), http://web.mit.edu/krugman/www/islm.html. I discuss critiques of the IS-LM model below.

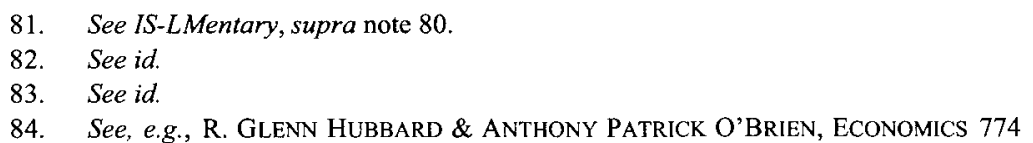
(5th ed., 2015) (showing a graph showing households spending a consistent fraction of each extra dollar of real disposable income on consumption, based on the U.S. Bureau of Economic Analysis data on real consumption spendings and real disposable income from 1960 to 2012); HARLAN M. SMITH, UNDERSTANDING ECONOMICS (1999) ("An examination of distribution data shows a rather consistent fraction of income for each quintile in the income distribution.").

85. See Hicks, supra note 7, at 153 fig.1, 153 n.8, 158. 
investment-savings market into balance without changing the interest rate $\left(i_{1}\right)$. In this case, output must decrease, reducing the supply of savings.

The decrease in output occurs as follows. Investment is a component of aggregate demand, ${ }^{86}$ while savings is a function of output. ${ }^{87}$ If savings exceeds investment, then aggregate demand falls short of output. Firms will find that they are now building up inventories, as the output they produce is no longer fully expended. In response, firms will cut output. This cut in output diminishes the supply of savings at this interest rate, so that the gap between savings and investment decreases. Inventories accumulate more slowly. If output falls enough, the given interest rate $\left(i_{1}\right)$ will finally equilibrate investment and savings. The IS curve in Figure 5 displays the set of interest rate and output combinations for which the amount of savings equals investment.

Now let us turn to the LM market, which determines the price of bonds relative to cash (the interest rate) as a function of output in the economy. The LM curve is upward sloping in the output, interest rate space (see Figure 5). As output rises, people want more cash to facilitate more transactions. To keep the demand and supply of cash in equilibrium at a higher output level, we need a higher interest rate, which makes interest-yielding bonds relatively more attractive. The LM curve displays the set of interest rate, output combinations for which the demand for cash (relative to bonds) equals the supply of cash, and it is upward sloping for that reason. ${ }^{88}$

Assume that we are at a combination of output and interest rate for which the IS market is in equilibrium but the demand for cash exceeds the supply of cash, such as Point $B$ in Figure 5. In response, the interest rate has to rise and/or output has to fall, in order to reduce the demand for cash relative to bonds and bring the LM market into balance. In order to reach equilibrium for both IS and LM markets, output needs to decrease and interest rates need to rise along the IS curve until we reach the unique interest rate output combination (Point $C$ ) that leaves both the IS and LM markets in equilibrium.

86. As stated above, aggregate demand is the sum of consumption, government spending, and investment (plus net export). See supra note 5 and accompanying texts.

87. See supra note 84 .

88. See Hicks, supra note 7 , at 153. 
Figure 5: IS-LM Model in Ordinary Times

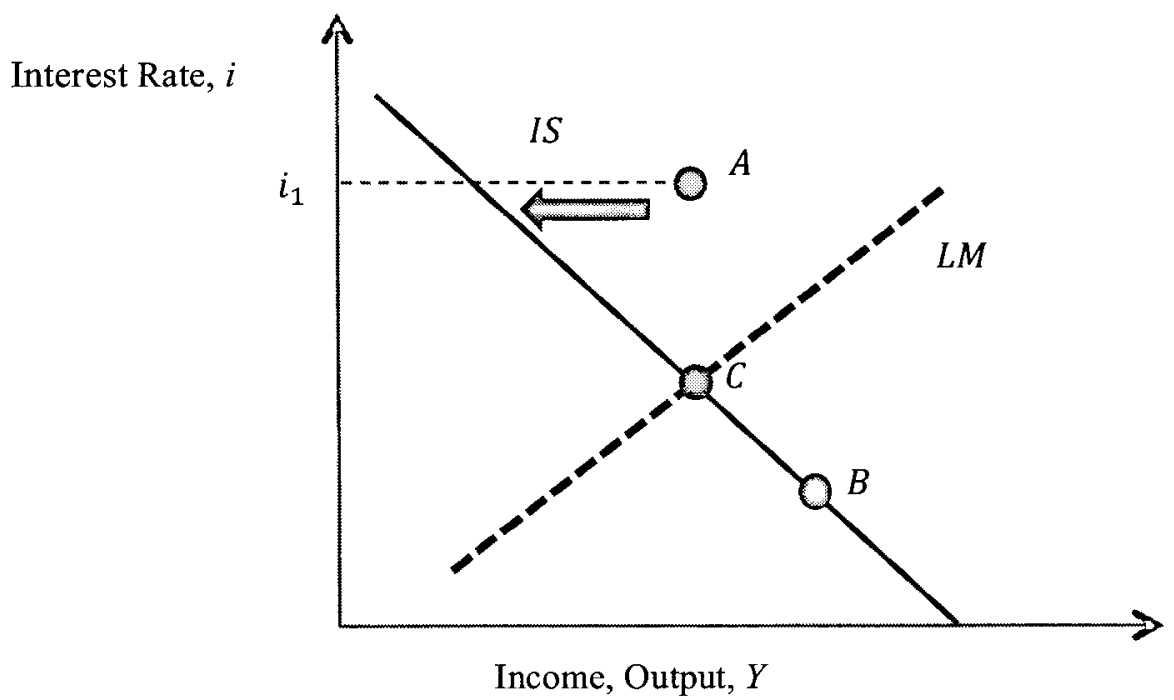

\section{IS-LM and the Zero Lower Bound on Interest Rates}

Let us use the IS-LM model to demonstrate that the economy functions differently at the zero lower bound.

Above, we demonstrated that the LM curve is upward sloping. ${ }^{89}$ When the output level decreases, there is less demand for cash relative to bonds in order to facilitate transactions. In order to balance the LM market, interest rates on bonds must decrease to induce individuals to hold cash rather than bonds.

However, this upward sloping relationship breaks down at the zero lower bound on interest rates. As discussed above, bonds cannot have negative interest rates. ${ }^{90}$ If they do, people would just prefer to hold cash. As a result, the LM curve becomes horizontal at zero interest rates. Once interest rates hit zero, decreases in output do not reduce people's demand for cash relative to bonds, and do not induce savers to switch to bonds. Instead, people stick with cash, regardless of the output amount. As a result, the IS-LM relationship is more accurately represented by Figure 6 below: the LM curve is upward sloping at interest rates above zero, but horizontal at the zero lower bound. ${ }^{91}$

89. See id.

90. See supra note 55 and accompanying text.

91. See Krugman, supra note 80; Evan F. Koenig, An IS-LM Analysis of the ZeroBound Problem, FED. RES. BANK OF DALlAS 6 (2011), http://www.dallasfed.org/assets/documents/research/staff/staff1 102.pdf. 
Suppose that the economy is in equilibrium in both the IS and LM markets at Point $C$ in Figure 6. Assume that, suddenly, the economy experiences a strong negative shock. This shock can have many different causes. For example, fears about the future may cause businesses and individuals to stop investing. With less investment-which is a component of aggregate demand-inventories accumulate as demand for spending falls short of output. Businesses lay-off workers and produce less until output equals the (lower) level of spending demand. At any given interest rate, investments and savings are going to be in balance at a lower level of output (denoted by $I S_{2}$ ) than they were previously (captured by $I S_{1}$ ). ${ }^{92}$ The new equilibrium of the economy is now at Point $D$.

Point $C$ in Figure 6 corresponds to a normal economy. Interest rates are well above zero, and output is not constrained by demand. Indeed, additional demand will most likely raise interest rates rather than output. Point $D$, by contrast, corresponds to a liquidity trap with much lower output (Y) and employment. Interest rates are zero at Point $D$ - they are constrained by the zero lower bound on interest rates.

Figure 6: IS-LM Model with the Zero Lower Bound on Interest Rates

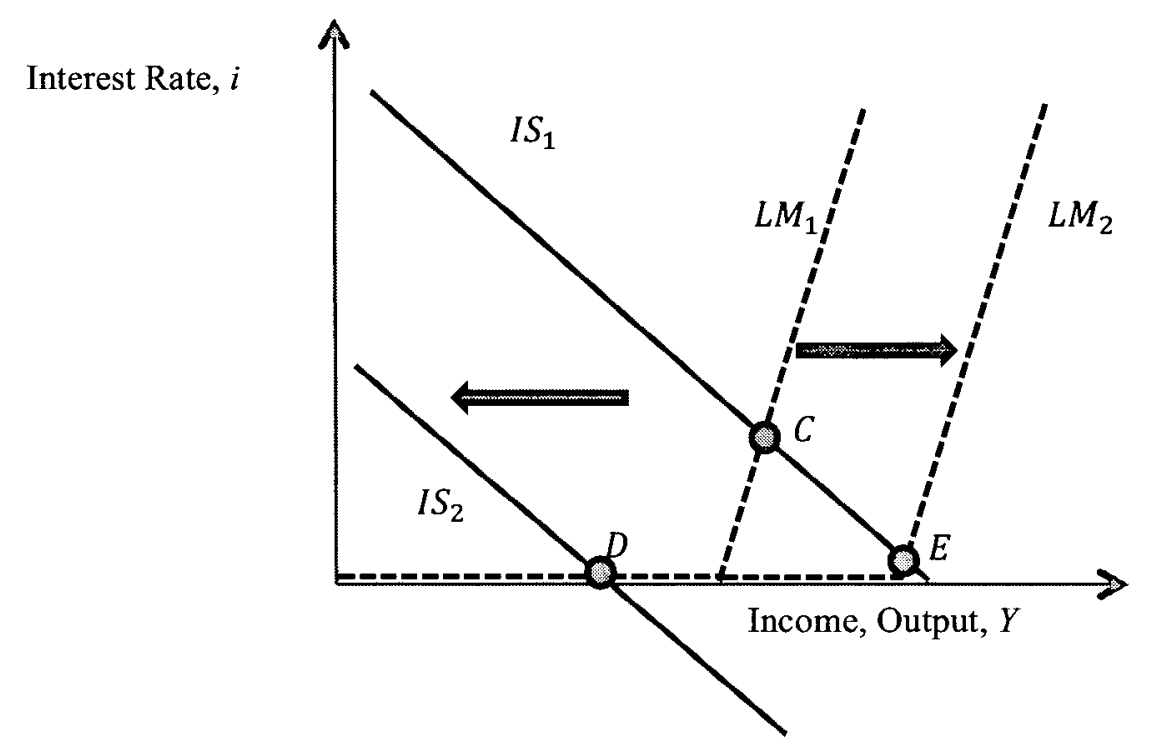

92. Note that previously in constructing the IS curve, we were discussing a change in the output level in response to a change in interest rates; all other things equal, a change in the interest rate or output level induces the point to change within a given IS curve. In contrast, here, we are discussing a change in economic output not in response to a change in interest rates but rather in response to another variable; this causes the IS curve itself to shift. Then, going back to our example of the strong negative shock, it causes the IS curve to shift inwards from $I S_{1}$ to $I S_{2}$. 
Economic policies work very differently at Point $C$ (which is unaffected by the zero lower bound) relative to Point $D$ (which is constrained by the zero lower bound). Policies work differently because the economy functions differently-increases in spending cause increases in output rather than increases in interest rates - the core of this Article's first claim.

\section{Differential Impacts of Monetary Policy at the Zero Lower Bound and In Ordinary Times}

Let us again consider Figure 6. Expansionary monetary policy can shift the LM curve outwards, for example from $L M_{1}$ to $L M_{2}$, because more money in the economy lowers interest rates and raises investment, all other things equal. ${ }^{93}$ The shift can stimulate the economy at Point $C$, moving the economy from Point $C$ to Point $E$. Output increases and interest rates decline. In contrast, expansionary monetary policy proves ineffective for an economy at Point $D$. At Point $D$, monetary policy cannot move interest rates below zero and so cannot move the LM curve "outward" or stimulate the economy. Output and interest rates remain at Point $D$, despite the expansionary monetary policy. In sum, the IS-LM model tells us that monetary policy at the zero lower bound becomes impotent.

\section{Differential Impacts of Fiscal Policy at the Zero Lower Bound and in} Other Times

Fiscal policy also causes different effects at Point $C$, which embodies an ordinary economic time, than at Point $D$, which represents a liquidity trap. Consider Figure 7. Assume that the economy is in equilibrium at Point $C$. The government passes a tax cut that raises consumption and raises the budget deficit. This stimulus package shifts the IS curve outward from $I S_{1}$ to $I S_{1}{ }^{194}$ Equilibrium in the economy moves from Point $C$ to Point $C$ '. There are two reasons to think that the change in output (i.e., the difference between Point $C$ and Point $C$ ' along the x-axis) is going to be marginal and temporary during ordinary economic times.

93. See JAMES D. GWARTNEY \& Richard STROUP, ECONOMICS: PRIVATE AND Public Choice A-11 (2014); MANKIW, supra note 9, at 305-06; N. GREGORY MANKIW \& LAURENCE BALL, MACROECONOMICS AND THE FINANCIAL SYSTEM 308-309 (2010); Hicks, supra note 7, at 157 ("[A]ny change in liquidity preference or monetary policy will shift the [LM] curve.").

94. See GWARTNEY \& STROUP, supra note 93, at A-11; N. GREGORY MANKIW \& Laurence Ball, Macroeconomics AND the FinanCIAL SySTEM 294-95 (2010); MANKIW \& Ball, supra note 93, at 294-95; Hicks, supra note 7, at 157 ("Any change in the inducement to invest or the propensity to consume will shift the IS curve."). 
Figure 7: IS-LM Model in Ordinary and Zero Lower Bound Times

Interest Rate, $i$

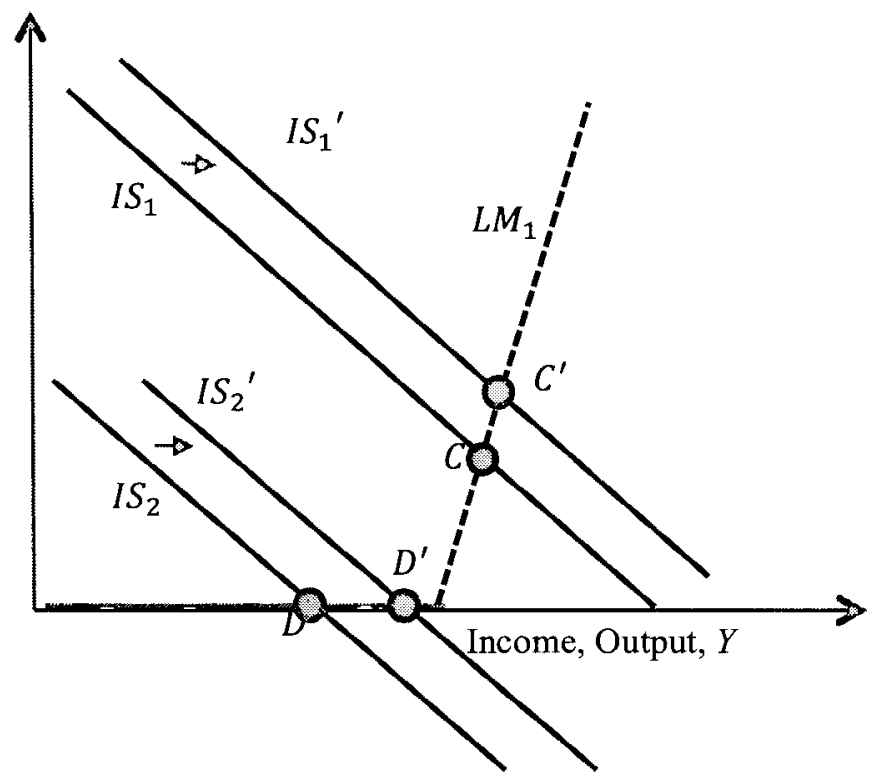

First, in an economy functioning normally, output is hard to increase via spending increases alone, ${ }^{95}$ and changes in demand primarily shift output from one place to another rather than causing it to increase dramatically. Reflecting this idea, the shapes of IS and LM curves should be such that the output does not increase much as a result of the fiscal stimulus (i.e., the LM curve would be steep and the IS curve relatively flat). Instead, a rise in interest rates should be the primary response. Indeed, the small increase in output from Point $C$ to Point $C^{\prime}$ that we see in the graph, if anything, exaggerates the increase in output. When the economy is working at its full potential like it does in ordinary times, and when there is an increase demand due to a fiscal stimulus, more demand does not translate to more output. Instead, increases in demand change interest rates and prices. ${ }^{96}$ These responses correspond to the predictions of classical economics $^{97}$ : more demand does not shift output which is determined by

95. In a normally functioning economy, output is determined by the size of the labor force, the stock of capital, and an economy's technological prowess. See supra note 4 and accompanying text. Fiscal policy lowering tax or increasing governmental spending does not affect any of these factors.

96. While the IS-LM model assumes sticky prices, in the long run prices can adjust (i.e., go up). Prices would go up in this case because, considering a standard two-dimensional space of output/income on the $\mathrm{x}$-axis and price on the $\mathrm{y}$-axis, aggregate supply determines output in normal economic times, and an increase in aggregate demand would only increase price level.

97. The "classical economists" was a "name invented by Marx to cover Ricardo and James Mill and their predecessors, that is to say for the founders of the theory which culminated in the Ricardian economics." JOHN MAYNARD KEYNES, GENERAL THEORY OF EMPLOYMENT, INTEREST AND MONEY 3 n.1 (Atlantic Publishers \& Dist. 2007) (1936). 
aggregate supply not aggregate demand. ${ }^{98}$ Aggregate demand can shift prices and interest rates, not output. ${ }^{99}$

Second, even if we concede that output increases in the short run due to changes in fiscal policy, the central bank would then adopt a monetary policy that offsets the increase in output. Assume that the economy was in balance at Point $C$ but is now running over-capacity at Point $C^{\prime}$. In response, to stabilize output and reduce the inflation associated with an over-heating economy, the central bank would tighten monetary policy, ${ }^{100}$ thereby pushing the LM curve inward and causing output to return closer to its level at Point $C .^{101}$ In other words, during ordinary times, monetary policy will function such that the effect of fiscal policy on economic output would be offset. ${ }^{102}$

As with monetary policy, the effects of fiscal stimulus are very different at the zero lower bound. At the zero lower bound, increases in demand utilize slack capacity and raise output significantly for two reasons.

First, increases in demand cause increases in output rather than changes in interest rates or inflation. Suppose that the government enacts a fiscal stimulus package when the economy is at Point $D$, shifting the IS curve outwards from $I S_{2}$ to $I S_{2}{ }^{\prime}$. As Figure 7 indicates, equilibrium in the economy moves from Point $D$ to Point $D^{\prime}$. In other words, the increase in spending demand translates into a rise in output. ${ }^{103}$ Interest rates remain unchanged at zero. At the zero lower bound, the increase in aggregate demand caused by fiscal stimulus does

98. See id. at 24 ("[T]he classical theory assumes ... that the aggregate demand price (or proceeds) always accommodates itself to the aggregate supply price; . . . a further increase in the value of the effective demand will no longer be accompanied by any increase in output ... . Thus Say's law ... is equivalent to the proposition that there is no obstacle to full employment"); KNOPP, supra note 4, at 36 ("Aggregate demand has no influence on real aggregate output [under the Classical model.]").

99. Id.

100. See J. Bradford DeLong \& Lawrence H. Summers, Fiscal Policy in a Depressed Economy, in BROOKINGS PAPER ON ECON. ACTIVITY 233, 243 (David H. Romer \& Justin Wolfers eds., 2012) ("When interest rates are away from their zero bound, when the output gap is small, or when high unemployment is not cyclical but structural, then either bottlenecks or monetary policy offset make it unlikely that fiscal expansion will impart any significant boost to real GDP. When that is so, there is no stabilization policy case for expansionary fiscal policy.").

101. The side effect is that interest rates may go up still further.

102. This notion of monetary offset against fiscal policy shocks may also apply in the case of fiscal austerity, although the effectiveness of the monetary offset has been hotly debated since the recent crisis. See, e.g., Scott Sumner, Why the Fiscal Multiplier Is Roughly Zero, 80 MERCATUS ON POL'Y 2 (2013), http://mercatus.org/sites/default/files/Sumner_FiscalMultiplier_MOP_090313.pdf; Edward Harrison, UK Fiscal and Monetary Policy Offset To Kick in, Bullish for Gilts, CREDIT WRITEDOWNS PRO. (July 1, 2016), http://pro.creditwritedowns.com/2016/07/uk-fiscal-and-monetarypolicy-offset-to-kick-in-bullish-for-gilts.html; R.A., Can the Fed Offset Contractionary Fiscal Policy?, ECONOMIST (Apr. 28, 2013), http://www.economist.com/blogs/freeexchange/2013/04/monetary-policy3; Simon Wren-Lewis, On the Monetary Offset Argument, MAINLY MACRO (Jan. 11, 2015), http://mainlymacro.blogspot.com/2015/01/on-monetary-offset-argument.html.

103. The increase in demand does not necessarily equal the size of the fiscal stimulus. Because of the Keynesian multiplier effect, the size of the shift in the IS curve is likely to be greater than the size of the stimulus. But the principle that increases in demand yield increases in output at the zero lower bound-is more important for our purposes than the size of the multiplier effect. 
not crowd out other investment or consumption much. ${ }^{104}$ Instead, it brings back into production the capacity that had been unused because the economy was sitting on cash. Output thus rises without interest rates changing.

Second, monetary policy cannot and does not want to counteract the effects of increases in aggregate demand, because it is constrained by the zero lower bound and would support an increase in output rather than counteracting it. ${ }^{105}$ When aggregate demand crashes (from $I S_{1}$ to $I S_{2}$ ), so that the "natural" rate of interest becomes negative, the central bank loses its ability to stimulate the economy. This negative natural rate may lead to deflation, which the central bank abhors. ${ }^{106}$ The increase in output from Point $D$ to Point $D^{\prime}$ due to fiscal policy assists the central bank in stimulating the economy, both to raise output and to avoid deflation. ${ }^{107}$ Fiscal policy reduces the likelihood of deflation by utilizing slack capacity, and the central bank would have no incentive to counter the fiscal policy as it would during ordinary economic times.

In an economy constrained by the zero lower bound on interest rates, increases in demand increase output. This effect corresponds to the Keynesian, and not the classical, prediction about the economy. In the Keynesian economy, aggregate demand, rather than potential output, determines total output.

The Hicksian IS-LM model thus reconciles the classical and Keynesian views of the economy. The rules of the classical economy apply to economies unconstrained by the zero lower bound (in equilibrium at Point $C$ ). In a classical economy, demand does not determine output. Instead, prices and interest rates adjust so that the economy produces at its capacity. The classical economy is the economy upon which law and (micro)economics is based. In contrast, at the zero lower bound (Point $D$ ), the rules of the Keynesian economy apply. Anything that increases aggregate demand increases output.

\section{F. Empirical Evidence that Economic Policies Have Different Effects at}

\footnotetext{
104. See Michael Woodford, Methods of Policy Accommodation at the Interest-Rate

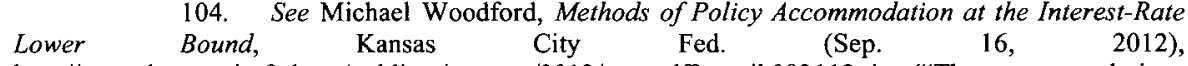
http://www.kansascityfed.org/publicat/sympos/2012/mw.pdf?sm=jh083112-4 ("The most obvious source of a boost to current aggregate demand that would not depend solely on expectational channels is fiscal stimulus-whether through an increase in government purchases, tax incentives for current expenditure such as an investment tax credit, or subsidies for lending like the [Funding for Lending Scheme announced by the Bank of England and the UK Treasury]."); Salim Furth, Research Review: Zero Lower Bound Interest Rates, HERITAGE (May 8, 2013), http://www.heritage.org/research/reports/2013/05/monetary-policy-and-zero-lower-bound-interest-rates ("In contrast, New Keynesian models suggest that when the interest rates relevant for investing are constrained by the zero lower bound, the crowding-out mechanism stops functioning and fiscal policy can be expansionary."). Also, note that aggregate demand is a sum of consumption, government spending, and investment. See supra note 5 and accompanying text.

105. See DeLong \& Summers, supra note 100, at 235.

106. See WENDY CARLIN \& DAVID SOSKICE, MACROECONOMICS: INSTITUTIONS, InSTABILITY, AND THE FInANCIAL SYSTEM 88 (2014); Elvis Picardo, Why Is Deflation a Central Bank's Worst Nightmare?, INVESTOPEDIA (Sep. 28, $\mathrm{http} / /$ www.investopedia.com/articles/investing/051315/what-deflation-and-how-do-central-banks-fightit.asp.
}

107. See supra Section III.D.2. 


\section{Different Times}

Hicks's synthesis of classical and Keynesian economics derives support from empirical research on fiscal multipliers. Multipliers capture the answer to the following question: what is the long-run effect of a one dollar increase in government spending on total output? A one dollar increase in government spending does not necessarily translate to a one dollar increase in output; output level may increase by more than one dollar, or less than one dollar. This is because a one dollar increase in governmental spending may simply reshuffle output-implying a multiplier of zero-or because a one dollar increase in governmental spending can have a multiplier effect as described below in this Section-implying a multiplier greater than 1. In Figure 7, I demonstrated that, in theory, the multiplier depends on the state of the economy. In ordinary economic times (Point $C$ ), a one dollar increase in government spending will have a smaller effect on output than the same increase would in a liquidity trap (Point $D$ ). Thus, the Hicksian IS-LM model developed above predicts the fiscal multipliers to be higher at the zero lower bound than in ordinary economic conditions

A significant empirical literature supports the proposition that fiscal multipliers are higher when interest rates are constrained by the zero lower bound. In 2012, the International Monetary Fund ("IMF"), which had historically deemed the multiplier to be of a low value of around .5 during ordinary economic times, ${ }^{108}$ asserted that "multipliers have actually been in the 0.9 to 1.7 range since the Great Recession. This finding is consistent with research suggesting that in today's environment of substantial economic slack [with] monetary policy constrained by the zero lower bound ... multipliers may be well above 1." 109 A later IMF working paper that summarized the empirical evidence on spending multipliers concluded:

108. See INT'L MONETARY FUND, WORLD ECONOMIC OUTLOOK 43 box 1.1 (Oct. 2012), http:/www.imf.org/external/pubs/ft/weo/2012/02/pdf/text.pdf.

109. Id. Furthermore, some recent empirical estimates of multipliers during periods of slack demand are 1.5 or more over three years. Alan J. Auerbach \& Yuriy Gorodnichenko, Measuring the Output Responses to Fiscal Policy, 4 AM. ECON. J.: ECON. POL'Y 1, 11, 19 (2012) [hereinafter Measuring the Output Responses]; see also Alan J. Auerbach \& Yuriy Gorodnichenko, Fiscal Multipliers in Recession and Expansion, in FISCAL POLICY AFTER THE FINANCIAL CRISIS 79 (Alberto Alesina \& Francesco Giavazzi eds., 2013) [hereinafter Fiscal Multipliers]. Other sources suggest that the multiplier is well above 1 during periods of slack. See, e.g., INT'L MONETARY FUND, FISCAL MONITOR, 33-39 (Apr. 2012), http://www.imf.org/external/pubs/ft/fm/2012/01/pdf $/ \mathrm{fm} 1201$.pdf; Nicoletta Batini et al., Successful Austerity in the United States, Europe, and Japan 23-25 (IMF Working Paper No. 12/190, 2012); Michael Woodford, Simple Analytics of the Government Expenditure Multiplier, 3 AM. ECON. J.: MACROECON. 1, 33 (2011). However, another paper suggested the multiplier to be .7 to .9 over two to four years, and argued that empirical evidence did not show that multipliers were higher in recessions. See Valerie A. Ramey \& Sarah Zubairy, Government Spending Multipliers in Good Times and in Bad: Evidence from U.S. Historical Data 39 tbl.1 (Nat'l Bureau of Econ. Research, Working Paper No. 20719, 2014). 
Fiscal multipliers are generally found to be larger in downturns than in expansions [based on Table 4 reporting empirical estimates from eight different papers, see footnote]. This is true both for fiscal consolidation and stimulus. A stimulus is less effective in an expansion, because, at full capacity, an increase in public demand crowds out private demand, leaving output unchanged (with higher prices). A consolidation is more costly in terms of output in a downturn ....

[M]ultipliers can potentially be larger, when the use and/or the transmission of monetary policy is impaired - as is the case at the zero interest lower bound (ZLB). Most of the literature focuses on the effect of temporary increases in government purchases and finds that the multiplier at the ZLB exceeds the "normal times" multiplier by a large margin.

There are thus strong theoretical and empirical reasons to presume that the economy works differently at the zero lower bound than it does in ordinary times. In ordinary times, policies that increase aggregate demand (spending) cause higher interest rates and inflation and, at best, slightly higher output temporarily (before interest rates rise and end the boom). At the zero lower bound, however, policies that increase aggregate demand raise output by utilizing slack capacity.

I should highlight the possibility that the fiscal multiplier can be greater than one. A dollar of additional spending can cause more than one dollar in additional output. How can this be? Consider a dollar of spending on infrastructure. The initial dollar of spending goes to pay wages, capital, and more. Infrastructure rises by one dollar. But the effects on aggregate demand do not end there. With higher wages, workers, in turn, increase their spending. For example, they may go out to meals at a restaurant. Thus, the initial dollar increase in governmental spending produces a dollar of spending on infrastructure and another increment of spending on restaurant meals. And with this higher income, restaurant owners would spend money elsewhere, and this iterative process repeats. At the zero lower bound, all of this additional spending becomes additional output rather than displaced output. Thus,

110. Nicoletta Batini et al., A Simple Method to Compute Fiscal Multipliers 10 (Int'1 Monetary Fund, Working Paper 14/93, 2014) (emphasis added) (internal citations omitted) (citing Measuring the Output Responses to Fiscal Policy, supra note 109; Measuring the Output Responses, supra note 109; Alan J. Auerbach \& Yuriy Gorodnichenko, Fiscal Multipliers in Japan (Nat'l Bureau of Econ. Research, Working Paper No. 19911, 2014); Nicoletta Batini et al., Successful Austerity in the United States, Europe and Japan (Int'l Monetary Fund, Working Paper 12/190, 2012); Anja Baum et al., Fiscal Multipliers and the State of the Economy (Int'l Monetary Fund, Working Paper 12/286, 2012); Matthew Canzoneri et al., Fiscal Multipliers in Recessions (Universitat Bern Discussion Paper 12-04, 2012); Pablo Hernandez de Cos \& Enrique Moral-Benito, Fiscal Multipliers in Turbulent Times: The Case of Spain (Bank of Spain, Working Paper 1309, 2013); Michael T. Owyang et al., Are Government Spending Multipliers Greater During Periods of Slack? Evidence from $20^{\text {th }}$ Century Historical Data (Nat'l Bureau of Econ. Research, Working Paper No. 18769, 2013)), http://www.imf.org/external/pubs/ft/wp/2014/wp1493.pdf. 
spending has a "multiplied" effect on the economy. "Estimates for the size of this multiplier at the zero lower bound can run as high as four times the original change in spending. ${ }^{112}$

\section{Laws Cause One Set of Effects In Liquidity Traps and Another Set of Effects in Ordinary Economic Conditions.}

Laws of all types may raise or lower aggregate demand. As a result, laws can have different economic effects when interest rates are constrained by the zero lower bound than in ordinary times. This Part describes how two very different legal decisions-the approval or rejection of the Keystone XL pipeline and the award of specific performance versus damages in the celebrated contracts case of Jacob and Youngs $v$. Kent-would have different economic effects at different phases of the business cycle.

\section{A. The Keystone XL Pipeline}

TransCanada, Inc. first proposed building a $\$ 3$ to $\$ 4$ billion pipeline to bring oil from western Canada's "oil sands" to the U.S. Gulf Coast in 2005. ${ }^{113}$ Because the pipeline crossed the Canada-U.S. border, the pipeline required the approval from the U.S. Department of State. U.S. law charged the State Department with determining whether or not the pipeline was in the "national interest," a "determination that includes economic, environmental, national security and foreign policy implications." 114 In 2008, TransCanada, Inc. submitted a pipeline proposal to the State Department. ${ }^{115}$ In late 2015, President Obama announced that the proposal had been rejected, "ending a seven-year review that had become a symbol of the debate over his climate

\footnotetext{
111. See Veronique de Rugy \& Jakina Debnam, Does Government Spending Stimulate

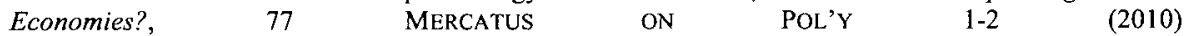
http://mercatus.org/sites/default/files/publication/MOP77_SBI_Spending\%20Multiplier_web\%20(2).pdf

112. See Christopher J. Erceg \& Jesper Linde, Is There a Free Lunch in a Liquidity

Trap? (Int'l Fin. Discussion Papers No. 1003, 2012),
http://www.federalreserve.gov/Pubs/ifdp/2010/1003/ifdp1003r.pdf. According to Batini et al., supra note 110, at 12, Christiano et al., Eggertson, and Erceg \& Linde report multiplier estimates at the zero lower bound that range from 2.3 to 4 . See Lawrence Christiano et al., When Is the Government Spending Multiplier Large?, 119 J. POL. ECON. 78, 93 (2011); Gauti B. Eggertsson, What Fiscal Policy Is Effective at Zero Interest Rates?, 25 NBER MACROECON. ANNUAL 59, 60 (2010); Erceg \& Linde, supra, at 3.

113. See Coral Davenport, Keystone Pipeline Pros, Cons and Steps to a Final Decision, N.Y. TIMES (Nov. 18, 2014), http://www.nytimes.com/2014/1 1/19/us/politics/what-does-theproposed-keystone-xl-pipeline-entail.html.

114. Id.

115. See Keystone XL Pipeline Evaluation Process Fact Sheet 2012, U.S. DEP'T STATE (last visited July 1, 2016), http://keystonepipeline-xl.state.gov/draftseis/205549.htm.
} 
policies." 116 President Trump signed an executive order approving the pipeline shortly after he assumed office. ${ }^{117}$ The proposed pipeline sparked enormous controversy. Considerations in favor of the pipeline included: securing reliable oil supplies for the U.S.; the generation of several thousand construction jobs; and the promotion of relations between the U.S. and Canada. ${ }^{118}$ On the downside, producing oil from the Canadian "oil sands" generates more carbon dioxide emissions than other types of oil production-a production process facilitated by the Keystone XL pipeline. In addition, building a pipeline entailed the risk of leaks that would cause environmental damage to sensitive ecosystems in the U.S.

The debate between those who favored the economic development associated with Keystone and those who feared its environmental effects simmered passionately for many years. This high salience has the advantage of making the subject familiar to readers but the disadvantage that many readers will already have strong views on the subject. In this discussion, I take no position on the absolute desirability or undesirability of Keystone. ${ }^{119}$ Instead, I show how the pipeline's desirability should depend on the state of the business cycle. Ardent opponents of Keystone may quite reasonably decide that, even in a liquidity trap, the pipeline should have been rejected. And advocates may reasonably conclude that the pipeline should have been approved in all circumstances. So long as I can show that the case for Keystone, however strong anyone thinks it is in the abstract, is stronger in a liquidity trap than under ordinary economic conditions, I will have achieved my aim.

The environmental benefits associated with denying Keystone XI may remain constant over the business cycle. The additional carbon dioxide emissions associated with Keystone XL would have caused harms for hundreds of years, long after many turns of the business cycle. But the economic costs of denying the Keystone XL pipeline depend on the business cycle. If Keystone $\mathrm{XL}$ was constructed during a liquidity trap, then approval of Keystone $\mathrm{XL}$ would have different effects than at other times.

Pipeline construction would have entailed considerable spending on labor and equipment. In terms of Figure 7, construction of Keystone XL would shift the IS curve outwards. The economic effects of this increase in aggregate demand on economic output, however, depend on the state of the business

116. Coral Davenport, Citing Climate Change, Obama Rejects Construction of Keystone XL Oil Pipeline, N.Y. TIMES (Nov. 6, 2015), http://www.nytimes.com/2015/11/07/us/obamaexpected-to-reject-construction-of-keystone-xl-oil-pipeline.html.

117. See Peter Baker \& Coral Davenport, Trump Revives Keystone Pipeline Rejected by Obama, N.Y. TIMES (Jan. 24, 2017), http://www.nytimes.com/2017/01/24/us/politics/keystonedakota-pipeline-trump.html.

118. See Davenport, supra note 114.

119. Indeed, as someone who takes the threat of climate change very seriously, I am not unhappy with the failure to build Keystone XL, although I think the political capital devoted to preventing Keystone XL could have more effectively mitigated carbon dioxide emissions if it had been deployed elsewhere. 
cycle. ${ }^{120}$ In 2005 , the year the Keystone XL pipeline was first proposed, this aggregate demand stimulus was unnecessary: the U.S. economy, and the construction sector in particular, was humming. ${ }^{121}$ Indeed, Keystone XL's stimulus to aggregate demand would likely have been offset by monetary tightening to cool the overheating economy. ${ }^{122}$ As a result, construction of Keystone XL Pipeline in 2005 would mostly have taken workers and capital from other projects rather than increasing output and employment. The year of 2005 corresponds to Point $C$ in Figure 7. As discussed above, during ordinary economic times, an increase in aggregate demand would raise interest rates and price rather than further increasing output that is already at an optimal level. ${ }^{123}$

In late 2010 and early 2011, however, when the State Department issued an initial environmental report and solicited public comments, the U.S. economy was mired in a liquidity trap, corresponding to Point $D$ in Figure 7 . Total construction spending was over a third less in 2010-2011 than its 2006 peak (see Figure 8). Short-term interest rates were zero in $2010-2011^{124}$ and long-term interest rates were exceedingly low. ${ }^{125}$ Monetary policy was constrained by the zero lower bound and so could not stimulate aggregate demand. As a result, the economy was constrained by a shortage of aggregate demand. Keystone XL would have meant an additional $\$ 3.4$ billion in construction spending, equal to $10 \%$ of the ARRA's stimulus spending on infrastructure projects. ${ }^{126}$ Keystone $\mathrm{XL}$ construction would have increased output, rather than reshuffling workers and capitals from other projects. The stimulus provided to aggregate demand by Keystone XL construction would thus have increased output rather than higher interest rates or prices.

120. See supra fig.7.

121. The U.S. GDP was growing at a rate of $6.52 \%$ in 2005 , see US GDP Growth Rate by Year, MULTIPL (last visited July 1, 2016), http://www.multpl.com/us-gdp-growth-rate/table/byyear, and the unemployment rate on January 1,2006 was at $4.70 \%$ which is very low, see US Unemployment Rate by Year, MulTiPL (last visited July 1, 2016), http://www.multpl.com/unemployment/table. The construction spending was rising a lot in 2005, peaking in 2006, which is a sign of the booming construction sector. See infra fig.9.

122. See supra notes 100-102 and accompanying text.

123. See supra notes $95-99$ and accompanying text.

124. See United States Fed Funds Rate, TRADING ECON. (last visited July 1, 2016), http://www.tradingeconomics.com/united-states/interest-rate.

125. See Long-Term Interest Rates, OECD (last visited July 1, 2016), http://data.oecd.org/interest/long-term-interest-rates.htm.

126. Recovery.gov indicates that the American Recovery and Reinvestment Act included $\$ 33.8$ billion in "infrastructure" funding excluding funding for transportation sector, as of April 2014. American Recovery \& Reinvestment Act: Breakdown of Funds Paid Out by Category, RECOVERYGOV (last visited Nov. 6, 2015), $\mathrm{http}: / / \mathrm{www}$. recovery.gov/arra/Transparency/fundingoverview/Pages/fundingbreakdown.aspx\#Contracts GrantsLoans. 
Figure 8: Total Construction Spending in the U.S. ${ }^{127}$

FRED.M

- Total Construction Spending

$1,300,000$

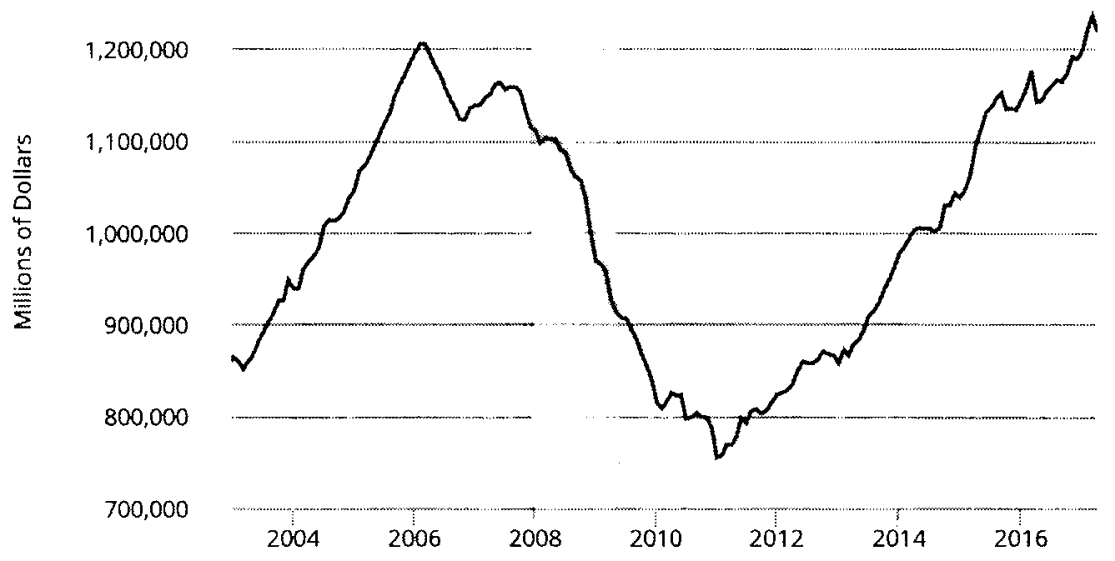

Source: U.S. Bureau of the Census

fred.stlouisfed.org

myf.red/g/eeBK

\section{B. Cost Benefit Analysis of the Keystone XZ Pipeline}

We can apply these time-varying economic effects to a hypothetical costbenefit analysis ("CBA") of the Keystone XL Pipeline. ${ }^{128}$

A standard, microeconomically precise, CBA would have evaluated Keystone XL as follows. ${ }^{129}$ Banning the pipeline imposes costs on consumers, investors, and workers. Consumers who would have bought oil from the pipeline must buy oil from elsewhere. With less supply, ${ }^{130}$ the world oil price will be (very) slightly higher. The cost of banning the pipeline to consumers is the resultant loss in consumer surplus. Investors own the machines used to

127. This is a custom-made graph from FRED Economic Data, FED. RES. BANK ST. LOUIS (last visited July 1, 2016), http://fred.stlouisfed.org/series/TTLCONS.

128. To my knowledge, the State Department did not conduct a formal cost benefit analysis of the Keystone XL pipeline. They did provide a detailed review of its economic and environmental effects. See Bureau of Oceans \& Int'l Env'l \& Sci. Affairs, Final Supplemental Environmental Impact Statement for the Keystone XL Project, U.S. DEP'T STATE (Jan. 31, 2014), http://keystonepipeline-xl.state.gov/documents/organization/221135.pdf [hereinafter "2014 Report"]; Bureau of Oceans \& Int'l Env'l \& Sci. Affairs, Final Environmental Impact Statement for the Keystone XL Project, U.S. DEP'T STATE (Aug. 26, 2011), http://keystonepipelineXl.state.gov/documents/organization/182010.pdf [hereinafter "2011 Report"].

129. For a standard CBA process, see, for example, E.J. MISHAN \& EUSTON QUAH, COST-BENEFIT ANALYSIS (5th ed. 2007); and RICHARD LAYARd \& STEPHEN GLAISTER, COST-BENEFIT ANALYSIS (1994).

130. If an alternative pipeline is built, then the world oil price will still be slightly higher because the alternative pipeline would be presumably less cost effective than the Keystone XL pipeline. 
build the pipeline, the land on which the pipeline would run, and the oil fields that will supply the pipeline. If the pipeline is banned, then investors must find alternative, and inferior, uses for this capital. Similarly, workers who would have worked on the pipeline must find alternative employment. The alternative jobs are likely to be worse than the jobs working on the pipeline, harming the workers. The sum of costs on (i) consumers, (ii) investors, and (iii) workers comprise the total costs of banning the construction of the Keystone XL Pipeline.

In reality, the practical application of CBA seldom meets the ideal just described. Not only are costs hard to measure, it is also a challenge to define the total scope of costs. For instance, CBA generally does not include costs of unemployment - a point emphasized by Masur and Posner. ${ }^{131}$

The benefits of denying the Keystone XL pipeline include the monetary value of the carbon dioxide emissions prevented, as well as the value associated with protecting the lands that the pipeline would have disturbed. While putting dollar values on these benefits is fiendishly difficult, let us assume that it has been done in some reasonable way. Assume that these environmental benefits remain constant over the business cycle.

Outside of a liquidity trap, our CBA is already done. If the benefits of denying the pipeline exceed the costs of denial, the State Department should deny approval. Otherwise, it should approve the pipeline. If the State Department knows the true costs and benefits of the pipeline, then CBA denies approval only when denial is microeconomically justified. ${ }^{132}$

131. See Masur \& Posner, supra note 30.

132. But in reality, we do not know the true costs and benefits of environmental regulations. A vast literature debates about whether to adopt the CBA in making regulatory decisions. To sum up these debates in two sentences: advocates of CBA like (among other things) the structural organization and rigor that CBA imposes on regulatory decision-making. See, e.g., Matthew D. Adler \& Eric A. Posner, Rethinking Cost-Benefit Analysis, 109 YALE L.J. 165 (1999); Eric A. Posner \& E. Glen Weyl, Cost-Benefit Analysis of Financial Regulations: A Response to Criticisms, 124 YALE L.J.F. 246, 247-57 (2015); Cass R. Sunstein, Financial Regulation and Cost-Benefit Analysis, 124 YALE L.J.F. 263, 270,274-75 (2015). Critics decry CBA's insistence on quantification of costs and benefits-i.e., can we meaningfully put a monetary value on species extinction?-and CBA's total neglect of distributional concerns. See, e.g., Frank Ackerman \& Lisa Heinzerling, Pricing the Priceless: Cost-Benefit Analysis of Environmental Regulation, 150 U. PA. L. REV. 1553, 1556 (2002) ("Indeed, we will argue, cost-benefit analysis is so inherently flawed that if one scratches the apparently benign surface of any of its products, one finds the [absurdity of assigning value to lives and other unquantifiable things]."); John C. Coates IV, Cost-Benefit Analysis of Financial Regulation: Case Studies and Implications, 124 YALE L.J. 882, 1011 (2015) (although in favor of the conceptual cost-benefit analysis, arguing that attempting to apply cost-benefit analysis to financial regulations would be "unfeasible" to carry out in a manner that is "precise, reliable, quantifiable"); Olof Johansson-Stenman, Distributional Weights in Cost-Benefit Analysis-Should We Forget About Them?, 81 LAND ECON. 337, 337 (2005) ("Many argue that it is socially inefficient to use distributional weights in cost-benefit analysis, and that doing so implies large inefficiency losses, when distributional matters can be dealt with through income taxation, instead. Our results question this view."); Jeff Schwartz \& Alexandra Nelson, Cost-Benefit Analysis and the Conflict Minerals Rule, 68 ADMIN. L. REV. 287, 346 (2016) (arguing that a quantifiable CBA "is not nearly the analytical tool that courts and policymakers seem to think it is" and arguing against "its required use in regulatory analysis"). 
At the zero lower bound, the aforementioned CBA would change. Because the economy functions differently at the zero lower bound than at other times, the boost to aggregate demand associated with the pipeline's construction leads to different effects than it would in ordinary times.

The costs of pipeline denial to workers are the most obvious difference between CBA in ordinary times and CBA at the zero lower bound. In a liquidity trap with excess unemployment, pipeline construction hires many workers who would otherwise be unemployed. Thus, the difference between approval and denial is not the difference between a worker's best job and his or her second best, as it would be in ordinary times. ${ }^{133}$ Instead, the approval or rejection of the project means the difference between having a job and not having a job. Pipeline construction at the zero lower bound creates jobs that otherwise would not have existed. Considering the staggering costs of unemployment during recessions, ${ }^{134}$ denial of the pipeline during recessions costs much more than it does in ordinary times.

133. Recall that prices and interest rates, rather than output and employment, are the primary effects of construction during ordinary economic times. See supra notes $95-99$ and accompanying texts.

134. See, e.g., Lawrence F. Katz, Long-Term Unemployment in the Great Recession, Testimony for the Joint Econ. Comm., U.S. Congress 3 (Apr. 29, 2010), $\mathrm{http} / / / \mathrm{scholar}$.harvard.edu/lkatz/files/long_term_unemployment_in_the_great_recession.pdf ("Much research demonstrates that permanently displaced workers and the long-term unemployed face particularly difficult labor market adjustments." (citing Wiji Arulampalam, Is Unemployment Really Scarring? Effects of Unemployment Experiences on Wages, 111 ECON. J. 577 (2001); Louis S. Jacobson et al., Earnings Losses of Displaced Workers, 83 AM. ECON. REV. 685 (2003); Kenneth A. Couch \& Dana W. Placzek, Earnings Lasses of Displaced Workers Revisited, 100 AM. ECON. REV. 572 (2010))); id. at 3 ("Workers displaced from long-term jobs in the early 1980s recession faced large earnings declines upon reemployment and still had 20 percent earnings losses at 15 to 20 years after displacement." (citing Till von Wachter et al., Long-Term Earnings Losses Due to Mass Layoffs in the 1982 Recession: An Analysis of U.S. Administrative Data from 1974 to 2004 (unpublished manuscript) (2009),

http://www.rand.org/content/dam/rand/www/external/labor/seminars/adp/pdfs/2009_wachter.pdf)); id. at 3 ("The health consequences of permanent job loss from long-term jobs are also severe for with a 50 to 100 percent increase in mortality the year following displacement, 10 to 15 percent increases in mortality rates for the next 20 years, and an implied loss of life expectancy for a worker aged 40 at displacement of 1 to 1.5 years." (citing Daniel Sullivan \& Till von Wachter, Job Displacement and Mortality: An Analysis Using Administrative Data, 124 Q.J. ECON. 1265 (2009))); id. at 3 ("The health problems and mortality increases from job loss are strongly positively associated with larger permanent earnings losses. A substantial number of permanent job losers also end up moving onto the disability insurance rolls as they become discouraged in searching for new jobs and often have many health problems." (citing David H. Autor \& Mark G. Duggan, The Rise in Disability Rolls and the Decline in Unemployment, 118 Q.J. ECON. 157 (2003))); id. at 3 ("Parental job loss also appears causally related to adverse impacts on children including poorer schooling outcomes and worse labor market outcomes as adults." (citing Philip Oreopolous et al., The Intergenerational Effects of Worker Displacement, $26 \mathrm{~J}$. LABOR ECON. 455 (2008); Ann Huff Stevens \& Jessamyn Schaller, Short-Run Effects of Parental Job Loss on Children's Academic Achievement, 30 ECON. ED. REV. 289 (2011))); Stephen D. Simpson, The Cost of Unemployment to the Economy, INVESTOPEDIA (Aug. 9, 2011), http://www.investopedia.com/financial-edge/0811/the-cost-of-unemployment-to-the-economy.aspx ("Unemployment leads to higher payments from state and federal governments for unemployment benefits ( $\$ 2.96$ billion worth of benefits were paid out in February 2017), food assistance, and Medicaid. At the same time, those governments are no longer collecting the same levels of income tax as before forcing the government to borrow money (which defers the costs and impacts of unemployment into the future) or cut back on other spending (perhaps exacerbating the bad economic situation). Unemployment 
A similar though less stark difference applies to capital. Construction requires a wide array of specialized and expensive machinery. If the pipeline was denied in ordinary times, then these machines would likely be deployed elsewhere. They might fetch a slightly lower rental price, but they would nevertheless be in use. In a liquidity trap, however, many of the machines are likely to be idle and earning nothing. Thus, the difference in returns to capital is much greater in liquidity traps than in ordinary economic times.

If the oil price increases as a result of the denial of the pipeline, then existing oil producers are slightly better off, while consumers are slightly worse off. The aggregate demand effects of this transfer from consumers to existing oil producers are not zero, however. Consumers likely have a higher marginal propensity to consume-are more likely to consume or invest an incremental dollar-than producers. Thus, a transfer from consumers to producers lowers aggregate demand, which depends on total consumption in the economy. In ordinary times, lower aggregate demand means lower interest rates and lower inflation but relatively stable output. In a liquidity trap, however, less aggregate demand means less output and employment. Thus, even if the direct costs to consumers of the denial of Keystone XL would be similar at the zero lower bound and when interest rates exceed zero, the knock-on effects of the wealth transfer are very different at the zero lower bound and imply that the costs of denying the pipeline are higher at the zero lower bound.

This macroeconomics-informed CBA does not mean that Keystone XL should have been rejected in 2005 (i.e., ordinary economic times) nor does it mean that Keystone XL should have been approved in 2011 (i.e., a liquidity trap). If Keystone XL's environmental harms were great enough, the State Department was justified in withholding approval in 2011. In contrast, if Keystone's environmental harms fell short of its benefits, then it should have been approved in 2005. Law and macroeconomics simply tells us that Keystone XL was a more attractive proposal in 2011 than in 2005: while the environmental benefits of denial remain the same in and out of liquidity traps as we assumed, a liquidity trap means that the costs of denial go up. If the cases for and against approval were evenly balanced in 2005, when Keystone XL's stimulus to aggregate demand was irrelevant, then approval should have been granted in 2011 , when output and employment were held back by inadequate aggregate demand.

is also a dangerous state for the U.S. economy. Over $70 \%$ of what the U.S. economy produces goes to personal consumption and unemployed workers."); D.M. The Jobs Recession, ECONOMIST (Mar. 16, 2012), http://www.economist.com/blogs/blighty/2012/03/economic-cost-recession ("[T]he actual number of employees has dropped by more than the fall in people in employment, which is propped up by the rise in self-employed and unpaid family workers. Those fortunate enough to find work often find themselves earning less than they did, with two-thirds reporting an average 'pay penalty' of $28 \%$, according to a CIPD poll."). 


\section{Conditional Approvals and Aggregate Demand}

To this point, I have assumed that the State Department's decision on Keystone XL was limited to a binary option of either banning or permitting the pipeline as proposed. But decisions are seldom so confined. Instead, regulators often impose conditional mandates. For example, Keystone XL could have been approved subject to certain conditions, such as adding safety measures. These conditions can enhance aggregate demand: constructing companies, having to comply with these additional conditions, would need to purchase more resource and hire more workers, which raises aggregate demand in the economy. In other areas of law, regulators often impose conditional mandates. For example, the EPA often permits power plants to operate, so long as they install new devices that reduce pollution. ${ }^{135}$ When we introduce the availability of regulatory conditions into our CBA model, law and macroeconomics does not simply prescribe that the approval or rejection of Keystone XL should be more likely at the zero lower bound relative to other times. Instead, it recommends that any regulatory decision that enhances aggregate demand should be given more weight at the zero lower bound than at other times.

Instead of the binary option of banning or approving Keystone XL, the State Department could conditionally approve the pipeline. Indeed, in early 2011:

TransCanada agree[d] to adopt 57 project-specific special conditions for
design, construction, and operations of the Keystone XL pipeline. The
conditions [were] developed by the Department of State and the Pipeline
and Hazardous Materials Safety Administration; according to the
Supplemental Environmental Impact Statement, these conditions would
give the Keystone XL pipeline "a degree of safety over any other typically
constructed domestic oil pipeline .....136

The fifty-seven conditions to improve safety included improved pipeline monitoring systems, expanded pipeline testing, and enhanced construction requirements. ${ }^{137}$ Complying with these conditions entailed hiring more labor and buying more capital than building without the conditions. This conditional mandate would also have increased spending and raised aggregate demand. Again, at the zero lower bound, more aggregate demand means more output and lower unemployment.

135. The Mercury and Air Toxics Standards were proposed by the EPAA in 2012 to reduce air pollution, and they impose regulations regarding pollution control devices that would reduce harmful pollutants. See Mercury and Air Toxics Standard: Clean Power Plants, U.S. ENVTL. PROTECTION AGENCY (last visited Nov. 6, 2015), http://www3.epa.gov/mats/powerplants.html.

136. Keystone XL: \#TimeToBuild, ENERGY \& COMMERCE COMM. (last visited Nov. 6 , 2015), http://energycommerce.house.gov/content/keystone-xl.

137. See Bureau of Oceans \& Int'l Envtl \& Sci. Affairs, Final Environmental Impact Statement: Keystone XL Pipeline, U.S. DEP'T ST. ES6-ES8 (Aug. 26, 2011), http://keystonepipelinexl.state.gov/documents/organization/182010.pdf. 
Suppose that the conditions imposed on Keystone XL would not have been justified in 2005. The costs exceeded the environmental benefits; in other words, those workers and capitals could have been more valuable and useful elsewhere, and using these resources for environmental compliance would have been too costly compared to the environmental benefits. CBA therefore dictates that the conditions should not have been imposed on the pipeline.

A law and macroeconomic perspective changes the CBA for 2011. Complying with the State Department's safety conditions would require additional spending. In a liquidity trap like 2011, this stimulus to aggregate demand would raise, rather than redistribute, output. Many of the workers and capital employed in making the pipeline safer would have been idle but for the construction of the pipeline and the imposition of the added conditions. As a result, the social costs of complying with the conditions in 2011 would have been relatively low, and may have even been close to zero. ${ }^{138}$ Compliance with the conditions would have provided environmental benefits. Thus, the liquidity trap of 2011 raised the chances that the State Department's conditions were more likely to be economically justified than the same conditions would have been in 2005 .

\section{Remedies in Contract}

To demonstrate the enormous scope of law and macroeconomic ideas, let us consider a very different legal context than Keystone-the appropriate remedy for breach of contract.

Consider the seminal contract law case of Jacob and Youngs v. Kent (the Reading Pipe case). ${ }^{139}$ In Jacob and Youngs, a contract between a rich landowner and a developer called for the developer to use Reading brand Pipe when constructing a home for the landowner. However, the developer used other brands of pipe when building the home. The brands were identical in quality to Reading Pipe, but they were not the stipulated Reading brand.

Both sides in Jacob and Youngs agreed that the developer breached the construction contract. The dispute was, in part, over remedies. The developer argued that substantial performance had been provided, so that the remedy should be nominal monetary damages; the landowner argued that performance was defective and the remedy should be more imposing, possibly including knocking down the newly constructed home and reconstructing it with Reading brand pipe (or alternatively, a much higher amount of monetary damages). ${ }^{140}$

138. Keynes famously called for hiring workers to dig holes and refill them because of the multiplier effects of their consumption. See JOHN MAYNARD KEYNES, THE GENERAL THEORY OF EMPLOYMENT, INTEREST AND MONEY 116 (Atlantic Publishers \& Dist. 2007) (1936).

139. 230 N.Y. 239 (1921).

140. For a discussion of the similarity between very high damage awards and specific performance, see Steven Shavell, Specific Performance Versus Damages for Breach Of Contract, 84 TEX. L. REV. 831, 839-40 n.33 (2006) ("It should be noted that specific performance itself might be 
Justice Benjamin Cardozo, writing for four members of New York's high court, favored the builder. A dissent filed by the other three Justices called for a more dramatic remedy, such as the mandatory rebuilding of the house with Reading brand pipe.

Traditional law and economics scholars, as well as academics writing from other perspectives, continue to dispute the appropriate remedy in Jacob and Youngs. ${ }^{141}$ Specific performance-forcing the builder to knock down the house - appears to be a draconian remedy. But the contract in Jacob and Youngs clearly specified Reading Pipe and explicitly gave Kent the right to demand specific performance if the building was not completed as specified. As a result, some scholars argue that, even if specific performance in Jacob and Youngs seems inefficient, it is necessary to give the right incentives for parties to read contracts carefully and perform. ${ }^{142}$

I do not take a position on the existing debate. Instead, I want to highlight that different remedies have different effects on aggregate demand. If the developer has to knock down and rebuild the house, then aggregate demand is higher than if the developer has to pay monetary damages. ${ }^{143}$ As a result, courts facing Jacob and Youngs-like cases should prefer a remedy of specific performance at the zero lower bound. When interest rates exceed zero, by contrast, the effects of the remedy on aggregate demand are less germane because interest rate movements will offset much or all of the proximate effects on spending. The existing scholarly debate, however, ignores macroeconomic conditions entirely.

Because courts and regulators make remedial decisions in every case, the cumulative effect of remedial decisions on aggregate demand can be substantial. Remedies, like substantive legal standards, can be used to stimulate aggregate demand.

interpreted as a very high measure of damages, for if a substantial enough sum would have to be paid for breach, there would presumably be no breach (in the absence of the judgment-proof problem).").

141. The debate among traditional law and economics scholars concern fairness, microeconomic efficiency, waste, and so forth, without any macroeconomic consideration. For more information on this debate, see, for example, RICHARD A. POSNER, ECONOMIC ANALYSIS OF LAW 88-89 (2d ed. 1977); Robert Birmingham, Breach of Contract, Damage Measures, and Economic Efficiency, 24 RUTGERS L. REV. 273 (1970); Robert Birmingham, Damage Measures and Economic Rationality: The Geometry of Contract Law, 1969 DUKE L.J. 49 (1969); Richard R.W. Brooks, The Efficient Performance Hypothesis, 116 YALE L.J. 568 (2006); Daniel Friedmann, The Efficient Breach Fallacy, 18 J. Legal Stud. 1 (1989); Anthony T. Kronman, Specific Performance, 45 U. CHI. L. REV. 247 (1979); and Alan Schwartz, The Case for Specific Performance, 89 YALE L.J. 271 (1979).

142. See, e.g., Jody S. Kraus \& Robert E. Scott, Contract Design and the Structure of Contractual Intent, 84 N.Y.U. L. REV. 1023, 1095-97 (2009).

143. Even if the court decides that the landowner has the right to a house with Reading Brand pipe, the landowner and the developer may privately agree for the developer to pay higher damages in exchange for the landowner relinquishing the right to a house with Reading brand pipe. If this occurs, then aggregate demand will be unchanged as there will be no additional construction. But the chance of additional construction activity is much higher if the court decides that the landowner has the right to Reading brand pipe rather than if the court decides that the landowner has the right to a nominal monetary remedy. As a result, aggregate demand will be at least as high, if not higher, when the court awards the injunctive "specific performance" remedy, rather than a monetary remedy. 


\section{Laws Should Be Different at the Zero Lower Bound}

In the previous two Parts, we have seen that economies function differently at the zero lower bound than at other times and that the efficiency of legal decisions such as the decision to approve, conditionally approve, or reject the Keystone XL pipeline changes accordingly. In this Part, I argue that law should therefore be different at the zero lower bound than when short-term interest rates significantly exceed zero. ${ }^{144}$ In the next Part VI, I will discuss objections to my assertion that law should be dependent on economic conditions.

Law and economics favors legal decisions that are efficient. Approval of Keystone XL may have been "efficient" according to a CBA in 2011 but not in 2005. Likewise, imposing additional spending conditions on Keystone XL may have been "efficient" according to a CBA in 2011 but not in 2005.

If law should be efficient and what is efficient changes with the business cycle, then law surely needs to change with the business cycle. If someone considers the Keystone XL pipeline a close-call but not in the national interest in ordinary times, then it should have been approved in 2011 , but rejected in 2005 and 2017.

As a general matter, law should be different at the zero lower bound than at times in which the interest rate exceeds zero. Laws and regulations that promote spending become more attractive at the zero lower bound. To keep things simple, I argue that law should ignore macroeconomic factors in ordinary economic conditions. However, at the zero lower bound, law should seek to maximize aggregate demand.

But this does not mean that law should strive only to promote spending during liquidity traps. Instead, promotion of aggregate demand at the zero lower bound should be one goal among many others such as microeconomic efficiency, equity, environmental considerations, dignity values, and so forth. If these other considerations strongly counsel against the ruling that does the most to promote spending, then the legal ruling should not promote spending, even at the zero lower bound. For instance, if the State Department decides that building the Keystone XL Pipeline would be an environmental disaster, then it should reject Keystone XL's application, regardless of the state of the economy. The environmental harms outweigh the benefits of higher aggregate demand - even at the zero lower bound.

The Keystone analysis also applies to the issue of efficient remedy in $J a c o b$ and Youngs. If a court was just barely inclined toward a monetary remedy over specific performance during ordinary economic times, then the court should be more favorable to specific performance at the zero lower bound

144. See infra Section VI.B for a discussion on why law should promote spending when short-term interest rates are barely above zero and unemployment rates are high. 
since specific performance would raise aggregate demand via reconstruction of the home.

We can even go further and quantify the degree to which the state of the economy should play a role in making legal decisions. As the spending multiplier ${ }^{145}$ - which is quantifiable-increases, promotion of aggregate demand should play an increasingly important role in any legal calculus that considers economics. When the multiplier is high, the likelihood that additional spending employs idle capital and labor is higher, and thus a decision that promotes spending becomes increasingly attractive.

Having established the central policy prescription of law and macroeconomics - that law should promote spending in liquidity traps-I now turn to institutional constraints on the application of law and macroeconomics.

\section{Institutional Barriers to Law and Macroeconomics}

Even if you agree with claims (1) and (2)-that the economy works differently at the zero lower bound and that laws have business-cycle-varying economic effects, you may be against claim (3)-that law should vary with the state of the economy. The primary concern is that law may be institutionally incapable of making reasonable macroeconomic policy. If so, then we may decide that law and macroeconomics is not worth the trouble, even if it is theoretically justified. In this Part, I discuss, and ultimately reject, institutional barriers to the practical application of law and macroeconomics.

\section{A. Critiquing Law and Macroeconomics in Practice}

\section{The Likelihood of Effective Law and Macroeconomic Policymaking Is} Low

Lawyers generally have little expertise in macroeconomics. Macroeconomics is not taught in law schools. Even after law school, lawyers rarely confront macroeconomic policy questions. Attorneys may argue that a legal outcome is microeconomically inefficient, unfair, inequitable, or morally wrong. But they seldom, if ever, consider the macroeconomic effects of their desired outcomes. As a result, lawyers do not obtain experiential education in macroeconomics.

Policymakers with other types of training, such as public policy or MBA degrees, probably understand macroeconomics better than lawyers.

145. This Article discussed the notion of fiscal spending multipliers-how a dollar increase in government spending leads to output change in the economy by an amount that is not necessarily a dollar -earlier in supra notes 108-113 and accompanying texts. The idea is the same here; even if the Keystone XL project would not be a governmental fiscal policy per se (i.e., government is not injecting its own money), an increase in the initial spending by TransCanada would have a larger (or smaller) ramification than the direct expense it makes, due to multiplier effects discussed above. 
Introductory courses in economics devote considerable space to macro. Any Masters or Ph.D. level economist working for an agency will have taken several semesters of courses in macroeconomics. But even for those with some macroeconomic training, macroeconomic sophistication probably lags behind other areas of expertise. When the EPA conducts a cost-benefit analysis of a new environmental rule, for example, it engages scientists, epidemiologists, and economists to measure the benefits and costs of the rule. Macroeconomic costs are not considered, and economists who specialize in macroeconomics are not hired by the EPA. ${ }^{146}$

Even if lawyers were macroeconomic experts, it would be hard for them to get macroeconomic policy right. Economies are subject to a never-ending array of shocks. Commodity prices, geopolitical tensions, asset price fluctuations, weather, and many other events stimulate or inhibit aggregate demand. Some of these shocks are transitory and can be ignored by policymakers; bad weather, for example, inhibits aggregate demand, but its effects dissipate quickly. Other shocks have longer lasting effects. In realtime, it is hard to disentangle the aggregate demand effects of many different events and respond appropriately. Even experts in macroeconomics, such as central bankers and specialists, debate the relevance of some events versus others. If macroeconomic policy is hard for the experts, then it will be doubly hard for lawyers.

In addition, the legal decision that promotes spending will not always be clear cut. Consider adding spending requirements to the Keystone XL Pipeline as a condition of approval. ${ }^{147}$ The additional environmental mandates tied to Keystone XL in 2011 would have increased aggregate demand, ${ }^{148}$ assuming that the mandates were followed. However, if the mandates were too strict, then TransCanada might have withdrawn the project. If TransCanada withdrew the project because of the cost of the mandates, then the mandates would have inhibited aggregate demand. The State Department would have promoted maximum aggregate demand only if it imposed spending conditions on the pipeline that fall just short of the point at which TransCanada would abandon the project, but finding that precise point would be an extremely difficult task.

In addition to the difficulties lawyers would have identifying macroeconomic fluctuations and choosing appropriate responses, most recessions are too short-lived for legal policy to provide an effective response. ${ }^{149}$ Suppose that aggregate demand plunges for ten months - the

146. For example, the National Center for Environmental Economics, a research office of the EPA, employs many economists, but relatively few who work in sub-disciplines of economics that relate to macroeconomics. See Staff Profiles, U.S. ENVTL. ProteCTION AGENCY (last visited Nov. 12, 2015), http://yosemite.epa.gov/ee/epa/eed.nsf/webpages/Staff.html.

147. See supra notes $136-137$ and accompanying texts.

148. Id.

149. The 1945 Recession lasted about 8 months; the 1949 Recession lasted about 11 months; the 1953 Recession lasted about 10 months; the 1957 Recession lasted about 8 months; the 1960 Recession lasted about 10 months; the 1970 Recession lasted about 11 months; the 1973-1975 
average post-WWII recession before the recent Great Recession was 10.4 months ${ }^{150}$-and that lawyers notice and want to respond. Unfortunately, most of the lawyer's tools do not move quickly enough to make a difference. Consider Keystone XL. Above, I argued that Keystone XL approval would enhance aggregate demand. Approval, however, moves slowly-the first comprehensive State Department report on Keystone XL was issued three years after the initial proposal. ${ }^{151}$ Even if the State Department decided that it wanted to change its approval standards to stimulate aggregate demand, its decision would come long after a typical recession had ended.

In sum, legal policymakers are not macroeconomic experts. What is hard for the experts at the central bank or financial regulators will be even harder for lawyers who are untrained in macroeconomics. Moreover, legal policy that stimulates aggregate demand works slowly. Given these obstacles, we might reasonably decide that the likelihood of effective law and macroeconomic policymaking is so low that it is not worth trying.

\section{The Costs of Considering Macroeconomics in Legal Decisions Are High}

One may argue that, if law is ill placed to respond to macroeconomic fluctuations relative to other policy vehicles, then we should not include macroeconomics as a legal decision-making criterion. When legal decision makers consider macroeconomics, they have less scope to pursue other goals of law, such as microeconomic efficiency, equity, simplicity, predictability, and more. At times, policymakers may choose a policy that looks bad from a nonmacroeconomic perspective if the macroeconomic benefits are high enough. This may be a tradeoff worth making if there are real benefits. But if law cannot improve macroeconomic policy as a practical matter, then law and macroeconomics imposes these costs without an offsetting benefit. Consider the microeconomic efficiency costs of imposing specific performance in Jacob and Youngs v. Kent. Many commentators have argued that a draconian remedy like specific performance will induce inefficient waste in some circumstances. ${ }^{152}$ In Jacob and Youngs, for example, it seems incredibly wasteful to tear down and rebuild a home because its pipes are the wrong

Recession lasted about 16 months; the 1980-1982 Recession consisted of two recessions, first lasting 6 months and the latter lasting 16 months; the 1990-1991 Recession lasted 8 months; and the 2001 Recession lasted 8 months. See U.S. Business Cycle Expansions and Contractions, NAT'L BUREAU ECON. RES. (Sep. 20, 2010), http://www.nber.org/cycles.html.

150. See id.

151. See The Keystone XL Pipeline Timeline, WALL ST. J. (Apr. 24, 2014), http://blogs.wsj.com/washwire/2014/04/24/the-keystone-xl-pipeline-timeline/.

152. See, e.g., Shavell, supra note 124. For a summary of the debate about the efficiency of specific performance in Jacob and Youngs and an argument that specific performance was the efficient remedy, see Alan Schwartz \& Robert E. Scott, Market Damages, Efficient Contracting, And the Economic Waste Fallacy, 108 CoLUM. L. REV. 1610 (2008). 
brand. ${ }^{153}$ Thus, awarding specific performance to enhance aggregate demand may compromise microeconomic efficiency. And while specific performance should only be chosen as the remedy if the macroeconomic gains exceed the microeconomic losses, there is no doubt that there are costs to microeconomic efficiency from adding another criterion for legal judgments.

Adding macroeconomics to the list of decision-making criteria also gives judges more scope to impose their own policy preferences. A policy that conforms to a judge's or administrator's personal preferences may have little support from microeconomic efficiency or equity considerations. Without law and macroeconomics, the judge or administrator may be compelled to rule against their private interest, which lacks good sources of support.

When we introduce macroeconomics, however, we give the judge or administrator another degree of freedom. The decision that comes closest to the decision maker's personal preferences may be supported by macroeconomics. If we added all the considerations up and weighted them appropriately, then the policy may be undesirable, despite its macroeconomic benefits, because the policy's efficiency, equity, and moral costs outweigh its macroeconomic benefits. But it would be hard for those who review decisions to evaluate the decision maker's calculus. An incorrect decision justified by macroeconomic considerations may stand even if it is the wrong decision. The availability of a macroeconomic argument gives the decision makers a chance to impose personal preferences.

Finally, adding macroeconomics to the legal policy calculus seemingly reduces law's predictability and simplicity. Adding another factor to a legal decision complicates decisions when they are already far from transparent.

\section{There Are Better Venues than Law for Making Macroeconomic Policy}

The value of expansionary legal policy cannot be considered in a vacuum. Rather, expansionary legal policy should be compared to alternative options for stimulating aggregate demand. If these options suffice, then there may be no need for law and macroeconomics.

\section{a. Monetary Policy}

Some specialized government bodies-central banks-focus on macroeconomic policy. Central banks employ an array of macroeconomic experts. Unlike other policymakers, central bankers can credibly evaluate the macroeconomic effects of the myriad shocks to the economy.

153. Granted, the waste will be lower in a liquidity trap because we are utilizing slack capacity rather than moving production from another purpose. Unless the multiplier is very high, however, knocking down a house just to rebuild it is inefficient even in a recession. 
Central banks also have effective macroeconomic policy tools at their disposal. Monetary policy-through which central banks control short-term interest rates and influence long-term rates ${ }^{154}$-allows central banks to stimulate or inhibit the entire economy in response to shocks. This contrasts with the tools available to other legal policymakers. Even important decisions, such as approving or rejecting the Keystone $\mathrm{XL}$ pipeline, have much smaller macroeconomic consequences than systemic changes in interest rates.

Moreover, central banks' decision-making apparatus is responsive by design. Monetary policy decisions are usually made by a vote of macroeconomic experts at scheduled meetings approximately every month. ${ }^{155}$ At any meeting, central banks can change policy in response to a shock to aggregate demand. And under pressing circumstances, central banks can meet as frequently as needed to alter policy. ${ }^{156}$ As a result, central banks have a short "inside" lag. This contrasts with the long delays that accompany some legal decisions (e.g., Keystone $\mathrm{XL}^{157}$ ). With such a disparity in time lags between central banks and other institutions, we might decide that time-varying macroeconomic policy should be restricted to the fast-moving central banks rather than other slow-moving agencies.

\section{b. Fiscal Policy}

However, monetary policy is not always effective. During liquidity traps, the zero lower bound prevents interest rate reductions. As a result, monetary policy cannot stimulate investment through lowering short-term interest rates. ${ }^{158}$ In these situations, however, we can fall back on expansionary fiscal policy. Increased government spending and tax cuts stimulate aggregate demand. ${ }^{159}$ Moreover, some of the fiscal stimulus is automatic. ${ }^{160}$ With discretionary and automatic fiscal policy backing up monetary policy during

154. See supra notes $72-73$ and accompanying texts.

155. In the United States, the Federal Open Market Committee (FOMC) of the Federal Reserve meets eight times a year to decide monetary policy. See Bd. of Governors, What Is the FOMC and When Does It Meet?, FED. RES. SYS. (last visited Nov. 12, 2015), http://www.federalreserve.gov/faqs/about_12844.htm. The Governing Council of the European Central Bank meets twice monthly. See Monetary Policy Decisions, EUR. CENT. BANK (last visited 12, 2015), http://www.ecb.europa.eu/mopo/decisions/html/index.en.html. The Monetary Committee of the Bank of England meets monthly. See News Release - Monetary Policy Committee Dates for 2015 and Provisional Dates for 2016, BANK OF ENGLAND (last visited Nov. 12, 2015), http:/www.bankofengland.co.uk/publications/Pages/news/2014/119.aspx. The Bank of Japan holds Monetary Policy Meetings fourteen times per year. See Monetary Policy Meetings, BANK OF JAPAN (last visited Nov. 12, 2015), http://www.boj.or.jp/en/mopo/mpmsche_minu/index.htm.

156. In the United States, for example, the FOMC "may also hold unscheduled meetings as necessary to review economic and financial developments." Bd. of Governors, supra note 155 .

157. See The Keystone XL Pipeline Timeline, supra note 151 and accompanying text.

158. See supra notes $75-78$ and accompanying texts.

159. See supra Section III.E.3.

160. For a textbook discussion on automatic stabilizers, see N. GREGORY MANKIW, PRINCIPLE OF ECONOMICS 292-94, 446-48 (7th ed. 2015). 
liquidity traps, we might conclude that there is little scope for legal policy to stabilize the economy.

\section{B. Why Law and Macroeconomics Applies in Practice as Well as Theory During Liquidity Traps}

The practical arguments against using macroeconomic considerations are strong. Putting it all together, law provides an imperfect tool for implementing macroeconomic policy. I agree. In ordinary times, I think macroeconomic considerations should be irrelevant for law. But when monetary policy is ineffective (i.e., in a liquidity trap), law offers an important and practical avenue for stimulating aggregate demand.

\section{The Stakes Are So High and the Alternatives Are Weak}

Let me begin by re-stating the stakes. The Great Recession cost the U.S. alone between $\$ 6$ trillion and $\$ 14$ trillion of output. ${ }^{161}$ On the high end, that is two-years' worth of production. And the lost output was not evenly shared. Workers who lost their jobs bore, and continue to bear, a disproportionate share of the costs of the recession. The Great Recession may have done even more harm to Europe. In addition to catastrophic unemployment rates and trillions of euros of lost output, ${ }^{162}$ the effects of the Great Recession have produced an existential crisis for the post-World War II European political order. ${ }^{163}$

Events like the Great Recession and its political after-effects also undermine simplicity and predictability, which may in turn undermine economic and social life even after aggregate demand has recovered.

If macroeconomic fluctuations cause harms of this magnitude, then we should be open to almost any policy that mitigates the harms. Although

161. See Atkinson et al., supra note 17, at 1 .

162. See Loukas Tsoukalis, Steering Europe Out of the Crisis, POL'Y NETWORK PAPER 6 (2012), http://www.policy-network.net/publications download.aspx?ID=8201 ("Compared to the 5-year average trend, the slowdown of GDP growth rates since 2008 has led to an output loss of more than two trillion euro for EU-27 and more than one trillion for the Eurozone.").

163. The sovereign debt crisis involving Greece, Portugal, Ireland, Spain, and Cyprus-which was part of the Great Recession - and the recession generally threatened the unity of the European Union. See, e.g., Barry EICHENGreen, Hall of Mirrors: The Great DePression, the GREAT RECESSION, AND THE USES-AND MISUSES-OF HISTORY 350 ("[T]he Troika succeeded in transforming the Greek crisis into an existential crisis for the euro and the European Union."); Edwin M. Truman, Unraveling the Euro Crisis, PETERSON INS. INT'L ECON. (Jan. 26, 2012), http://piie.com/commentary/speeches-papers/unraveling-euro-crisis ("[T]he crisis is existential for the European project as a whole."); Diego Muro \& Guillem Vidal, Mind the Gaps: The Political Consequences of the Great Recession in Europe, LONDON SCH. ECON. \& POL. SCI. BLOG (June 10, 2014), http://blogs.Ise.ac.uk/eurocrisispress/2014/06/10/mind-the-gaps-the-political-consequences-ofthe-great-recession-in-europe ("The economic crisis that started in September 2008 has widened three gaps between: (1) citizens and institutions; (2) debtor and creditor countries; and (3) citizens themselves. As a matter of fact, the Great Recession has inflicted serious damage to the European project while aggravating already existing gaps that pose a threat to the consolidation of the EU as a union of citizens rather than a confrontation of state interests."). 
introducing macroeconomics to law will impose some costs, the stakes are so high that it is worth considering, even at the cost of microeconomic efficiency, equity, or simplicity. Law should respond to this pressing economic and social concern just as it typically responds to new economic and social developments by attempting to ameliorate them.

If we had good alternatives to using law to stimulate the economy at the zero lower bound, then the case for law and macroeconomics would be weaker. But we do not. The two most popular tools of macroeconomic policymonetary policy and fiscal policy-both lose efficacy at the zero lower bound.

As I have emphasized repeatedly, the zero lower bound on interest rates constrains conventional monetary policy during deep recessions. Interest rates cannot go (much) below zero. As a result, monetary policy, which is the preferred instrument for macroeconomic stimulus, is not available.

When ordinary monetary policy is constrained by a liquidity trap, central banks may turn to unconventional monetary policy. But unconventional monetary policy entails significant risks and uncertain benefits. Consider The Economist's review of one form of unconventional monetary policyquantitative easing:

The jury is still out on [quantitative easing], however. Studies suggest that
it did raise economic activity a bit. But some worry that the flood of cash
has encouraged reckless financial behaviour and directed a firehose of
money to emerging economies that cannot manage the cash. Others fear
that when central banks sell the assets they have accumulated, interest
rates will soar, choking off the recovery. [In 2013], when the Fed first
mooted the idea of tapering [long-term bond purchases], interest rates
around the world jumped and markets wobbled. Still others doubt that
central banks have the capacity to keep inflation in check if the money
they have created begins circulating more rapidly. Central bankers have
been more cautious in using QE than they would have been in cutting
interest rates, which could partly explain some countries' slow
recoveries.

If monetary policy is less effective in a liquidity trap, what about the other traditional remedy for aggregate demand shortages-expansionary fiscal policy?

Similarly, fiscal policy is a deeply flawed macroeconomic policy instrument. Indeed, many of the critiques of law as a macro policy instrument apply to fiscal policy. Legislatures are not any more famous for macroeconomic expertise than lawyers - they may be slow to recognize recessions and quick to propose poor solutions. Expansionary fiscal policy may be further constrained by legislative processes designed to make enacting

164. R.A., What Is Quantitative Easing?, ECONOMIST (Mar. 9, 2015), http:/www.economist.com/blogs/economist-explains/2015/03/economist-explains-5. 
legislation difficult. This instrumental design may be justified in ordinary times, but it exacerbates liquidity traps. Engaging in fiscal stimulus also compromises other goals of fiscal policy, which include the provision of public goods and redistribution, and the ability of the legislature to maintain a balanced budget over the business cycle.

The costs of engaging in fiscal stimulus are so high that many jurisdictions limit or even forbid themselves from engaging in stimulus. In the U.S., for example, state and local governments are bound to keep annual balanced budgets. ${ }^{165}$ Article 126 of the Treaty of the European Union stipulates, "Member States shall avoid excessive government deficits." 166 Unlike American states, European Union members can run budget deficits - so long as the deficits are lower than 3\%. Moreover, budget deficits higher than $3 \%$ are more likely to be permitted during "severe economic downturns,"167 retaining some macroeconomic flexibility. But fiscal flexibility in recessions in the Eurozone remains limited, as shown by the fiscal tightening required of many struggling European Union countries during the Great Recession. ${ }^{168}$

In a jurisdiction with a balanced budget amendment, expansionary fiscal policy is not a plausible substitute for law and macroeconomics. And even in jurisdictions without such requirements, the concerns that animate the establishment of balanced budget rules suggest that fiscal policy is not a clearly superior macroeconomic policy instrument to law.

With both monetary policy and fiscal policy compromised at the zero lower bound, law is one of the few policy levers powerful and ubiquitous enough to have important macroeconomic effects. Law affects almost every economic decision. A sustained effort to promote spending via appropriate adjustments to law would almost certainly have a pronounced positive impact

165. All fifty states within the United States have some form of balanced budget requirement. States are allowed to issue debt for capital expenditures, such as road construction. Ongoing expenses, however, must be covered by current revenues. In fact, these balanced budget requirements are imperfect. For example, off-budget items, such as obligations for future pension or healthcare payments, may be excluded from the balanced budget requirement. See, e.g., James M. Poterba, Balanced Budget Rules and Fiscal Policy: Evidence from the States, 48 NAT'L TAX J. 329 (1995); Daniel Shoag, The Impact of Government Spending Shocks: Evidence on the Multiplier from State Pension Plan Returns (2015) (unpublished manuscript). In spite of these imperfections, however, research suggests that balanced budget requirements curtail state government spending. See Poterba, supra.

166. Consolidated Version of the Treaty on the Functioning of the European Union art. 126, Sep. 5, 2008, 2008 O.J. (C 115 ) 99 [hereinafter TFEU].

167. See Council Regulation (EC) No 1467/97, 1997 O.J. (L 209) 6-11, summarized at The Corrective Arm: The Excessive Deficit Procedure, EUR-LEX (last visited Nov. 12, 2015), http://eur-lex.europa.eu/legal-content/EN/TXT/?uri=uriserv:125020\#amendingact.

168. See, e.g., Julio Escolano et al., Global Monetary Tightening: EmERging Markets DebT DYNAMICS AND FISCAL CRISES (2014); Ruben Atoyan et al., The Pre-Crisis Capital Flow Surge to Emerging Europe: Did Countercyclical Fiscal Policy Make a Difference? (IMF Working Paper No. 12/222, 2012), http://ssm.com/abstract=2169766; Giancarlo Corsettï \& Gernot Müller, Has Austerity Gone Too Far?, VOXEU.ORG (Feb. 20, 2012), http://www.voxeu.org/article/has-austeritygone-too-far; Marina Karanikolos et al., Financial Crisis, Austerity, and Health in Europe, 381 LANCET 1323 (2013); Philip R. Lane, The European Sovereign Debt Crisis, 26 J. ECON. PERSP. 49 (2012). 
on aggregate demand. Given the exceedingly high costs of liquidity traps and the absence of good alternatives, law and macroeconomics should be carefully considered at the zero lower bound.

\section{Are the Costs of Using Law for Macroeconomic Ends Really So High?}

We should also not exaggerate the gravity of some of the most salient critiques of using law for macroeconomic ends. It is true that macroeconomics is difficult and lawyers do not know much about it. But this is an argument for learning about macro, rather than giving up. Microeconomics is hard to learn, too, but that did not stop law and (micro)economics scholarship. Instead, lawyers became increasingly proficient at economics, producing better decisions.

Instead of giving up, we should improve legal training in macroeconomics. Basic proficiency in macroeconomics is attainable with only one semester of undergraduate material-no more than it takes to learn microeconomics. Furthermore, macroeconomics is more intuitive than microeconomics in some ways. The idea that output is determined by demand rather than supply fits with day to day observation. In any establishment, a day's output is mostly determined by demand. Finally, many arguments about the intersection of law and economics resonate with macroeconomics rather than microeconomics. The idea that regulatory prohibitions "kill jobs" - a common argument made in disputes before the EPA or local zoning boardsdoes not make much sense in microeconomic terms. In microeconomics, jobs are not killed; they are merely reallocated. But the argument makes sense in macroeconomic terms. Prohibiting investment inhibits aggregate demand and thus reduces employment in some circumstances.

Similarly, while the aggregate demand-maximizing legal ruling is hard to determine, this is true of most legal criteria. Consider microeconomic efficiency. In intellectual property law, for example, commentators are regularly comparing the deadweight losses associated with the creation of partial monopolies via patents and copyrights with the spur to innovation that these monopolies provide. ${ }^{169}$ The efficient law is unclear, but that has not meant we stop advocating microeconomic efficiency as a goal of law. Instead, we recognize that efficiency depends on many hard-to-know empirical factors but insist that efficiency frames the question coherently. The same attitude we have had with microeconomic efficiency should apply with the promotion of aggregate demand at the zero lower bound. Promotion of aggregate demand is a

169. See, e.g., Ian Ayres \& Paul Klemperer, Limiting Patentee's Market Power Without Reducing Innovation Incentives: The Perverse Benefits of Uncertainty and Non-Injunctive Remedies, 97 MiCH. L. REV. 985, 989-93, 999-1007 (1999); Gideon Parchomovsky \& Peter Siegelman, Towards an Integrated Theory of Intellectual Property, 88 VA. L. REV. 1455, 1462-65, 1479-81, 150110, 1517-19 (2002); Pierre Ragibeau \& Katherine Rockett, The Relationship Between Intellectual Property Law and Competition Law: An Economic Approach 11-13 (Univ. of Essex, Econ. Discussion Paper No. 581, 2014), http://repository.essex.ac.uk/2851. 
coherent criterion, even if the aggregate demand-promoting answer may not be obvious.

Indeed, regulators already estimate something that resembles the promotion of aggregate demand. As part of feasibility analysis - a complement to cost-benefit analysis - regulators "report the number of plants that will be forced to close and the number of firms that will be bankrupted under each regulatory alternative." ${ }^{\prime 10}$ Thus, the regulator estimates both the additional spending associated with a regulation and the job losses associated with the regulation. This Article asks such analysis to take a step further by noting that, using these estimates, the regulator can estimate the net effects of a regulation on aggregate demand and that, during a liquidity trap, the regulator (or any other legal decision maker) should place more emphasis on these aggregate demand effects.

Even without educating lawyers in macroeconomics, we can make the legal system's macroeconomics burden much simpler by restricting consideration of macroeconomics to the zero lower bound. Ordinary recessions are indeed hard to identify. They can also end too quickly for many legal solutions to have an effect. But these concerns do not apply to the liquidity traps that are the focus of this article. At certain times, macroeconomic considerations are so salient that they fall within a lawyer's ken. The Great Recession provides a good example. During the Great Recession, employment ${ }^{171}$ and output ${ }^{172}$ fell by much greater amounts than in any other post-WWII U.S. recessions. The Great Recession also lasted longer than any other post-WWII U.S. recession. ${ }^{173}$ The difference between the Great Recession and the typical recession can be seen in Figure 9 below. One of these recessions-the Great Recession in the red line-is just not like the others. Almost three years into the Great Recession, total employment in the U.S. was still $6 \%$ lower than its pre-recession peak, despite a growing population. In almost every other post-WWII recession, by contrast, employment exceeded its pre-recession peak three years after the beginning of the recession. The Great Recession in the U.S. was different in kind from ordinary recessions. And we can draw similar (or even more dramatic) figures for Europe during the Great Recession, ${ }^{174}$ and for many economies during the Great Depression of the 1930s.

170. Masur \& Posner, supra note 30, at 630.

171. See infra fig.9; see also Chart Book: The Legacy of the Great Recession, CENT. ON BUDGET \& POL'Y PRIORITIES (June 28, 2016), http://www.cbpp.org/research/economy/chart-bookthe-legacy-of-the-great-recession.

172. See The Recession and Recovery in Perspective, FED. RES. BANK MINNEAPOLIS (June 3, 2016), http://www.minneapolisfed.org/publications/special-studies/rip/recession-in-perspective.

173. See supra notes 149-151 and accompanying texts.

174. See supra notes 162-163. 
Figure 9: Percent Job Losses in Post WWII Recessions, Relative to Peak Employment Month, in the U.S. ${ }^{175}$

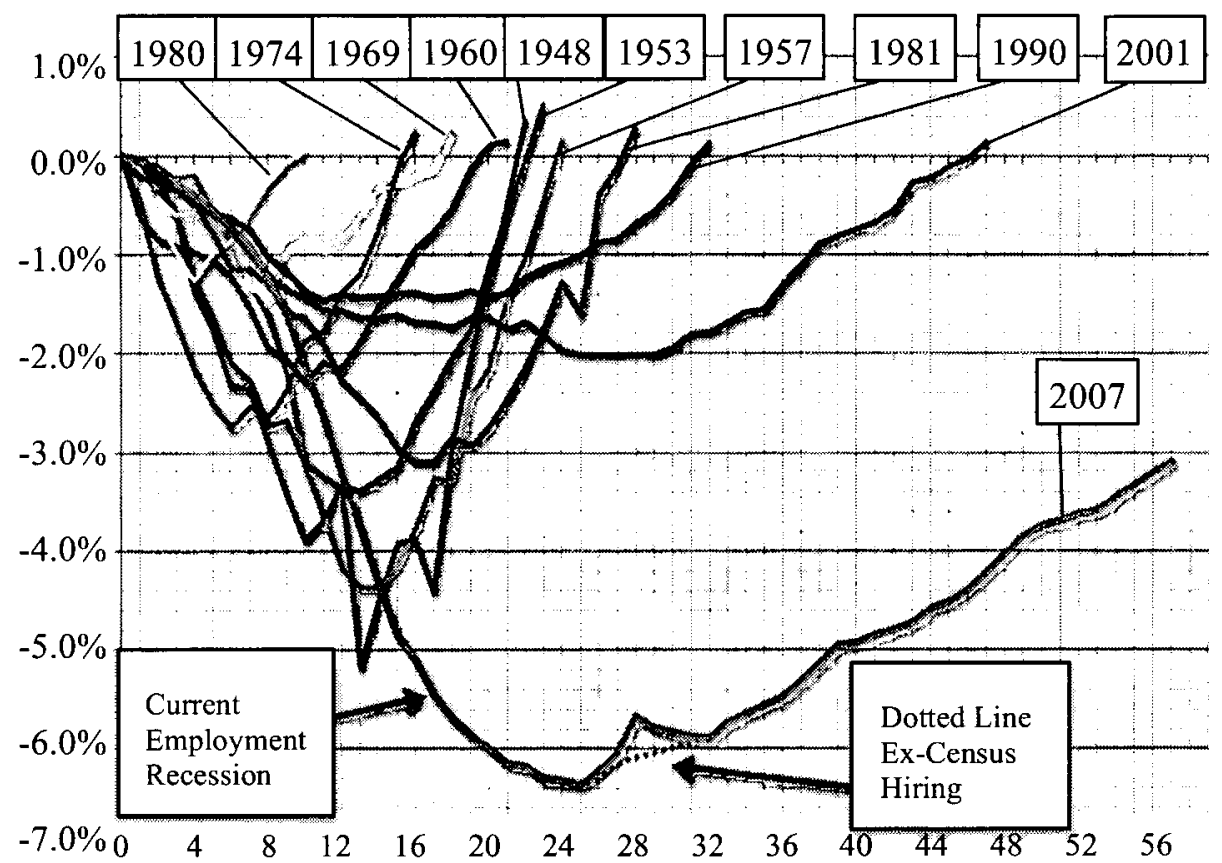

Number of Months After Peak Employment

Although ordinary recessions may be hard for lawyers to distinguish, post-financial crisis recessions or zero lower bound recessions are so severe and long-lasting that they are unmistakable. Indeed, there are often objective indicators of severe recessions-such as zero interest rates or historically high unemployment rates-that can be observed by picking up a newspaper. In addition, the worst recessions are unlikely to be caused by transitory shocks to the economy such as weather. Instead, the worst slumps last for years or even decades. ${ }^{176}$ These recessions call for a significant macroeconomic policy response - a response that lawyers can feasibly be a part of.

175. The chart is obtained from Joe Weisenthal, Chart of the Day: The Scariest Jobs Chart Ever, BUS. INSIDER (Nov. 2, 2012), http://www.businessinsider.com/chart-of-the-day-percent-joblosses-in-post-wwii-recessions-2012-11. Its formatting has been slightly modified for better visibility in the printed edition of the journal.

176. See Carmen M. Reinhart et al., Public Debt Overhangs: Advanced-Economy Episodes Since 1800, 26 J. ECON. PERSP. 69 (2012) (describing a public debt overhang which is associated with a sustained period of sub-par growth, lasting more than two decades sometimes). We should not be surprised by the difference between the Great Recession and other recessions. Unlike other post-WWII recessions, the Great Recession followed a financial crisis that undermined the banking sector. Recessions that follow financial crises tend to be much deeper and longer than other recessions. Indeed, according to Rogoff and Reinhart, the Great Recession in the United States and 
The length of zero lower bound recessions also mitigates another practical obstacle to law and macroeconomics. Legal policies change slowly-too slowly to respond to most recessions, which last an average of 10.4 months. ${ }^{177}$ But this critique is less relevant during liquidity traps. In the Great Recession, employment did not even begin to recover for almost three years. ${ }^{178}$ The Great Depression lasted a decade in some areas. ${ }^{179}$ On this time scale, law can respond effectively.

Again, Keystone XL proves illustrative. By 2011, the U.S. State Department had issued a comprehensive report on the costs and benefits of the pipeline. ${ }^{180}$ The report was three years in the making. ${ }^{181}$ An ordinary recession-and its aftermath-would already have been over. But this was not case for the Great Recession. In 2010-2011, employment was at its nadir ${ }^{182}$ - it would take years for the labor market to regain traction. Approval of Keystone XL to enhance aggregate demand in 2011 would thus have provided an effective and timely spur to aggregate demand.

Limiting consideration of macroeconomic factors to liquidity traps also fosters simplicity and predictability. Outside of a liquidity trap, law and macroeconomics does not change existing law-it has no impact on simplicity and predictability. And inside of a liquidity trap, law seeks to mitigate a daunting source of unpredictability by addressing macroeconomic policy problems. In total, I would therefore argue that law and macroeconomics enhances, rather than harms, simplicity and predictability.

In addition, liquidity traps are identified by an objective and hard-tomanipulate variable - short-term interest rates. As Figure 4 indicates, the worst slumps in modern U.S. history - the Great Depression and the Great Recession-have been characterized by zero short-term interest rates. And U.S. short-term interest rates have only reached zero during these two episodes. As a

elsewhere was a relatively mild post financial crisis recession compared to historical norms. See id. For more information on the Great Recession in the U.S. compared to other big post-financial crisis recessions in history, see Bill McBride, Employment Recovery: Great Recession, Great Depression, and Other Financial Crises, CALCULATED RISK FIN. \& ECON. (June 6, 2014), http://www.calculatedriskblog.com/2014/06/employment-recovery-great-recession.html.

177. See U.S. Business Cycle Expansions and Contractions, supra note 149 and accompanying text.

178. See supra fig.9.

179. It lasted a decade in the U.S. See U.S. Business Cycle Expansions and Contractions, supra note 149. For Canada, see James Struthers, Great Depression, HISTORICA CAN. (Mar. 4, 2015), http://www.thecanadianencyclopedia.ca/en/article/great-depression. For France, see J.H. Shennan, France, EnCYCLOPEDIA BRiTANNICA (last visited July 4, 2016), http://www.britannica.com/place/France/The-Great-Depression-and-political-crises ("Not until 1938-39 did a measure of recovery set in."). For Great Britain, see Nadeem Walayat, UK Recession WatchBritain's Great Depression?, GLoBAL RES. (Feb. 17, 2009), http://www.globalresearch.ca/uk-recessionwatch-britain-s-great-depression/12331 ("Britain's Great Depression in fact started in 1918 and did not end until 1937 and therefore lasted nearly 20 years.").

180. See 2011 Report, supra note 117.

181. See The Keystone XL Pipeline Timeline, supra note 151 and accompanying text.

182. See United States Unemployment Rate, TRADING ECON. (last visited July 3, 2016), http://www.tradingeconomics.com/united-states/unemployment-rate. 
result, we can point to an excellent proxy for the implementation of law and macroeconomic policies-zero short-term interest rates.

With an easy-to-identify proxy, law and macroeconomics does not entail an enormous sacrifice of simplicity and predictability. If a principle can be explained in one sentence contingent on an observable quantity (e.g., if shortterm interest rates are zero, then law should try harder to promote spending), then we should not be overly concerned about the loss of simplicity and predictability. No judge or regulator should attempt to promote aggregate demand when interest rates are unconstrained by the zero lower bound. When interest rates are above zero, monetary policy, a superior macroeconomic instrument, has room to promote aggregate demand.

One concern about using short-term interest rates as a proxy for consideration of macroeconomics is the possibility for discontinuous effects. If promotion of aggregate demand matters when short-term interest rates are zero but does not matter when short-term rates are at .1\%, then small and possibly idiosyncratic differences in interest rates can lead to big differences in legal rulings. In order to prevent these discontinuities, judges and regulators should also consider unemployment rates as a secondary consideration. If interest rates hover near zero (say below .25\%) and unemployment rates are high relative to recent experience (the two conditions almost invariably go together), then law should promote aggregate demand. Like short-term interest rates, unemployment rates are objective indicators that are hard to manipulate. And although introducing a second factor complicates macroeconomic judgments, the benefits in terms of making law and macroeconomics more robust to interest rate fluctuations justify the added complexity.

\section{Macroeconomic Considerations Will Be One Factor Among Many for Legal Policy Decisions}

The harm associated with letting decision makers consider macroeconomic conditions when making legal rulings should not be exaggerated. I do not claim that macroeconomics should be the only, or even the primary, legal decision-making criterion. Instead, law and macroeconomics is one of many factors, and it applies on the margin. Just as microeconomic efficiency gets balanced against other considerations, so too should promotion of macroeconomic stimulus.

We should also not exaggerate the risk of judges using macroeconomic rationales opportunistically to impose their personal preferences. Law already involves many degrees of freedom. A legal decision maker who wants to impose his or her personal preferences on a decision can already claim to apply fuzzy notions of efficiency, equity, justice, simplicity, and more. Adding macroeconomic considerations to legal decision-making does not create the problem of judicial discretion. At worst, law and macroeconomics slightly 
exacerbates an existing problem. Given the potentially large benefits of law and macroeconomics, this is a cost worth paying.

\section{Implementing Law and Macroeconomics}

Law and macroeconomics offers a plausible remedy to one of our most pressing problems. But who will implement aggregate demand promotion via law in liquidity traps? In brief, everybody-legislators, regulators, judges, lawyers, law enforcement officials, and so forth-should.

\section{Legislators}

Legislators should pass laws that promote aggregate demand at the zero lower bound. This includes, but is not limited to, laws that support expansionary fiscal policy, widespread debt relief, ${ }^{183}$ and the promotion of more efficient capital markets to assist investors in obtaining funding. ${ }^{184}$

\section{Regulators}

Regulators, and the executive branch more generally, should use their authority to promote aggregate demand. Keystone XL is the example I have emphasized, but almost every regulatory decision has some effect on spending. Consider the decisions of public utility regulators on rate increase requests by utilities. ${ }^{185} \mathrm{~A}$ rate increase is equivalent to a tax increase on consumers,

183. Debtors tend to have higher marginal propensity to spend than creditors, so money in the hands of debtors tend to increase aggregate demand more than money in the hands of creditors. See ATIF MiAN \& AMIR Sufi, House of DebT (2014).

184. Again, one of the components of aggregate demand is investment.

185. Distributing electricity, gas, or cable television to consumers entails high initial fixed costs, from turning on the generation facilities, building transmission facilities, and connecting customers to a grid. The marginal costs of supplying consumers one more unit of these services after the generation facility is turned on and connections are established are much lower than the average costs of providing these services, because of these high fixed costs. As a result, utilities are considered "natural monopolies" with high economics of scale; it is more efficient from a social welfare perspective to have one entity - or very limited few entities-provide utility services, rather than having many entities providing little bits of service.

Absent any regulations, monopolies can raise prices and inefficiently reduce output compared to socially optimal level of output, leading to consumer harms. In order to reduce these inefficiencies, utilities are generally regulated by the government. Instead of freeing utilities to set whatever price they deem fit, the government generally grants utilities a local monopoly and regulates the prices the utilities charge. When utility regulators work effectively, utilities should be charging prices that are efficient.

Utilities submit their proposed prices to regulators for approval at regular intervals. Utility regulation law governs when regulators should approve the proposed prices. "Cost of service" regulation sets rates so that utility investors recover their costs and receive a fair rate of return on investment. When a utility submits a price, regulators ask whether the proposed price gives investors a fair, but not excessive, return. The regulators also consider whether the utility's costs-including investment costs-are reasonable. Otherwise, the utility could simply raise profits through ever increasing investment. 
reducing discretionary income. The rate increase, however, provides more cash to the utility company. The effects of this redistribution depend on the marginal propensities to spend of the consumers relative to the utility company. If the consumers have a higher propensity to spend - a plausible assumption-then denial of a rate increase request raises aggregate demand. In a liquidity trap, this means more output. As a result, public utility regulators should be more likely to deny rate increase applications in liquidity traps than at other times, all other things equal.

\section{Judges}

Judges also need to be practitioners of law and macroeconomics. Laws and regulations enacted with a partial eye towards enhancing aggregate demand will have no impact if they are not understood and approved by judges.

Moreover, many judicial decisions have direct effects on spending. Consider a judge's decision to either grant a preliminary injunction to opponents of a development project or to allow the project to go forward but to impose damages if the opponents' suit is a winning one. Denying the preliminary injunction promotes aggregate demand by allowing the spending associated with a project to go forward. During a zero lower bound recession, a judge should be more inclined to deny a preliminary injunction than she/he would be during ordinary economic times, because promotion of aggregate demand has greater social value than in ordinary times.

\section{Enforcement Officers}

Enforcement decisions also affect aggregate demand. When the Internal Revenue Service ("IRS") collects more taxes via stricter enforcement, it implicitly tightens fiscal policy. When an enforcement issue is marginal from the IRS's perspective, they should be more likely to enforce in ordinary economic times and less likely to enforce during a liquidity trap. Likewise, when towns and cities impose fines, they implicitly tighten fiscal policy. As with IRS agents, collectors of fines should be more inclined to enforce fines in ordinary times and less likely to do so during liquidity traps.

\section{Law and Macroeconomics Already in Place}

In many ways, the question of who should implement law and macroeconomics is an unfair one. In law and microeconomics, we do not ask which officials should pursue microeconomic efficiency. Instead, we presume that everyone engaged with the legal system should have an understanding and

In Connecticut, the Public Utilities Regulatory Authority (PURA), approves all changes in utility rates. CONN. GEN. STAT. $§ 16-19$ (2014). PURA also publicly reviews gas and electricity rates every four years to ascertain that rates comply with the statutory guidelines. Id. 
inclination towards efficiency. Likewise, we do not ask which part of the legal system should pursue justice or equity-it is a systemic imperative. As it is the case with microeconomic efficiency and justice, so too should law and macroeconomics be pursued as part of the legal system.

Indeed, there are a number of ways in which law and macroeconomics has already been implemented, if in a way that is different from the way this Article has proposed. In the 1970 s, inflation, rather than stagnant economic growth, was the salient macroeconomic issue ${ }^{186}$ : the economy was not stuck in a liquidity trap but rather was at a point at which adding to aggregate demand led to higher interest rates and more inflation rather than more output. The Nixon and Ford administrations grew concerned that regulators were ignoring the macroeconomic effects of their policies. To compel the regulators to consider these effects, they required regulatory agencies to issue Inflation Impact Statements: "Major proposals for legislation, and for the promulgation of regulations or rules by any executive branch agency must be accompanied by a statement which certifies that the inflationary impact of the proposal has been evaluated." ${ }^{187}$ Specifically, the Director of the Office of Management and Budget was given authority to develop criteria for ascertaining a significant impact upon inflation, focusing on the effects on cost to consumers, productivity, competition, and supplies of important products. ${ }^{188}$ The subtext of these statements was clear. If a regulation increased inflation but was otherwise having marginal net benefit, the regulatory agency was supposed to rethink the regulation. In other words, the inflation impact statements were law and macroeconomics. Inflation Impact Statements would look very different in a liquidity trap-when the risk of inflation is low-than they would at other times, implying that law might vary across the business cycle. ${ }^{189}$

More famously, the "hundred days" of the Franklin D. Roosevelt ("FDR") administration represented a massive law and macroeconomic undertaking. ${ }^{190}$ First, FDR imposed a bank holiday, where banking transactions were suspended across the nation from March 6 to March 12, 1933. ${ }^{191}$ The bank

186. See Michael Bryan, The Great Inflation, FED. RES. HIST. (Nov. 22, 2013) ("The Great Inflation was the defining macroeconomic event of the second half of the twentieth century .... In 1964, when this story began, inflation was 1 percent and unemployment was 5 percent. Ten years later, inflation would be over 12 percent and unemployment was above 7 percent. By the summer of 1980 , inflation was near 14.5 percent, and unemployment was over 7.5 percent.").

(Nov. 29, 1974).

187. See Exec. Order No. 11,821, "Inflation Impact Statements," 39 Fed. Reg. 41,501

188. Id.

189. In this Article, I have rejected this type of law and macroeconomics. That is, I have not asserted that law should be used to constrain inflation. Instead, we should rely on monetary policy (increases in interest rates) to achieve this task. Law should only be used to promote aggregate demand when monetary policy is impotent. Thus, my vision of law and macroeconomics is less ambitious than the law and macroeconomics espoused by the Nixon and Ford administrations.

190. For more in depth information, see ANTHONY J. BADGER, FDR: THE FIRST HUNDRED DAYS (2009).

191. See William L. Silber, Why Did FDR's Bank Holiday Succeed?, FRBNY ECON. POL'Y REV. 19, 19 (2009). 
holiday exemplifies a business-cycle-varying law. During ordinary times, depositors are free to withdraw their money from banks. But in an economic crisis, the law changed so that depositors did not have this right to withdraw their money because all transactions were suspended during the holiday. ${ }^{192}$ Second, fifteen major laws were passed during the hundred days, ${ }^{193}$ and one focused on monetary policy. ${ }^{194}$ In addition to leaving the gold standard and promoting monetary stimulus, laws enabled providing credit to borrowers, ${ }^{195}$ providing more regulatory power to the Executive branch to stimulate economic recovery and raise prices after deflations, ${ }^{196}$ and more. While Title I of the National Industrial Recovery Act-a key component of the Act-was ultimately ruled unconstitutional, ${ }^{197}$ the vast scope of these laws show that, during the Great Depression, law, perhaps more than monetary or fiscal policy, was at the heart of efforts to revive an economy stuck at the zero lower bound.

Thus, law and macroeconomics attempts to reinvigorate an old policy tool rather than to create a new one.

\section{Conclusion}

This Article sought to provide a solid foundation for law and macroeconomics by resting it on three premises.

First, economies operate differently in liquidity traps than in ordinary times. At the zero lower bound on interest rates, output is constrained by a lack of spending and interest rates cannot adjust to mitigate the recession. When interest rates are constrained by the zero lower bound, decisions that increase spending increase output. In ordinary times, by contrast, capacity determines output. Public policy decisions to increase spending rearrange the pattern of spending rather than increasing output.

Second, laws operate differently at the zero lower bound. Laws affect spending. If spending has different effects in liquidity traps than at other times, then laws have different effects in liquidity traps. A law that is efficient when interest rate exceeds zero may not be efficient at the zero lower bound.

Third, laws should vary with the business cycle. If laws should be efficient and efficiency depends on the business cycle, then laws should be

\footnotetext{
192. See id.

193. See Kenneth T. Walsh, The First 100 Days: Franklin Roosevelt Pioneered the 100-Day Concept, U.S. NEwS (Feb. 12, 2009), http://www.usnews.com/news/history/articles/2009/02/12/the-first-100-days-franklin-rooseveltpioneered-the-100-day-concept.

194. FDR suspended the gold standard to avoid deflation. See WILliam E. Leuchtenburg, Franklin D. RoOSEvelT AND the New DeAL 51 (1963).

195. Homeowners' Loan Act of 1933, Pub. L. No. 73-43, 48 Stat. 128 (1933).

196. National Industrial Recovery Act of 1933, Pub. L. No. 73-67, 48 Stat. 195 (1933). This Act was called "the first major attempt to plan and regulate the economy." The First 100 Days, DigITAL HIST. (last visited July 3, 2016), http://www.digitalhistory.uh.edu/disp_textbook.cfm?smtid=2\&psid=3439.

197. See Schechter Poultry Corp. v. United States, 295 U.S. 495, 542 (1935).
} 
different at the zero lower bound than at other times. Specifically, law should promote aggregate demand in liquidity traps but focus on microeconomic efficiency at other times.

The third claim is likely to be the most controversial. Today, laws generally do not change with the business cycle. The costs of our ineffective response to the Great Recession, however, have been enormous. Millions of lives have been altered forever for the worse, and the politics of industrialized countries has taken a pronounced turn towards populism. If law can promote aggregate demand and mitigate the ongoing burden of the Great Recession, as well as the burden of future liquidity traps, the gains are almost incalculable.

Moreover, the idea that law should respond to a prolonged economic slump, or to the macroeconomic environment more generally, is less foreign than it may seem. The FDR, Nixon, and Ford administrations all practiced a form of law and macroeconomics. So should we.

An enormous amount of work remains in law and macroeconomics. Just as law and microeconomics has examined the microeconomic efficiency of vast bodies of law, law and macroeconomics also needs to evaluate the effects of these laws on aggregate demand. In addition, lawyers need some macroeconomic education. If lawyers have never been exposed to macroeconomic thinking, we cannot expect them-as legislators, regulators, judges, or executive officials-to consider macroeconomics when making law. It is my fervent hope that this Article helps begin this task. 